\title{
IMPACT OF COVID-19 ON THE VARIOUS SECTORS OF THE INDIAN ECONOMY AND ITS POLICY IMPLICATIONS
}

\author{
Hanisha Kochhar \\ SARLA ANIL MODI SCHOOL OF ECONOMICS, NMIMS UNIVERSITY \\ DOI: 10.46609/IJSSER.2021.v06i06.004 URL: https://doi.org/10.46609/IJSSER.2021.v06i06.004
}

\begin{abstract}
The COVID-19 Pandemic has generated an unforeseen health and economic crisis for the Indian economy. The Indian economy was already in a phase of slowdown before the inception of the virus. The elongated lockdown disrupted the demand and supply-side mechanisms of the economy. This study aims to examine the impact of COVID-19 on different sectors of the Indian economy by utilizing both primary and secondary sources of data. Through this study the extent of severity caused by the pandemic on the various sectors is determined. A primary research for understanding the reaction of the local economy in the era of Digital transformation is conducted. While several economic indicators, benchmarks and research papers are used in analyzing a particular sector. The final section of the paper puts forward policy implications and recommendations specific to each sector in order to overcome this pandemic infused economic downturn.
\end{abstract}

KEYWORDS: COVID-19, manufacturing, agriculture, informal, banking, service, MSMEs, trade, impact, sector

\section{Introduction}

Around mid-December 2019, Wuhan, one of the most popular cities in China, experienced an outbreak of coronavirus (COVID-19) caused by the severe acute respiratory syndrome coronavirus $2^{1}$ (Yang, Zhang, and Chen 2020). With more than 130 million confirmed cases globally with almost 2.8 million deaths, ${ }^{2}$ this disease has infected 216 countries worldwide. On $11^{\text {th }}$ March 2020, the World Health Organization classified the SARS-CoV-2 as pandemic. A pandemic is "An epidemic occurring over a very wide area (several countries or continents) and

\footnotetext{
${ }^{1}$ SARS-CoV-2

2 WHO Coronavirus Disease (COVID-19) Dashboard. (n.d.). Retrieved from https://covid19.who.int/?gclid=CjwKCAiAf78BRBbEiwATKRRBA91QloJQXRRXfa06rUSpbakAceD0iIRQQ5TXfardc4aDRi6bNuW-BoCDvIQAvD_BwE
} 
International Journal of Social Science and Economic Research

ISSN: 2455-8834

Volume:06, Issue:06 "June 2021"

usually affecting a large proportion of the population." (US Centers for Disease Control and Prevention). ${ }^{3}$

\section{Figure 1.1: COVID-19 Cases in India Overtime}

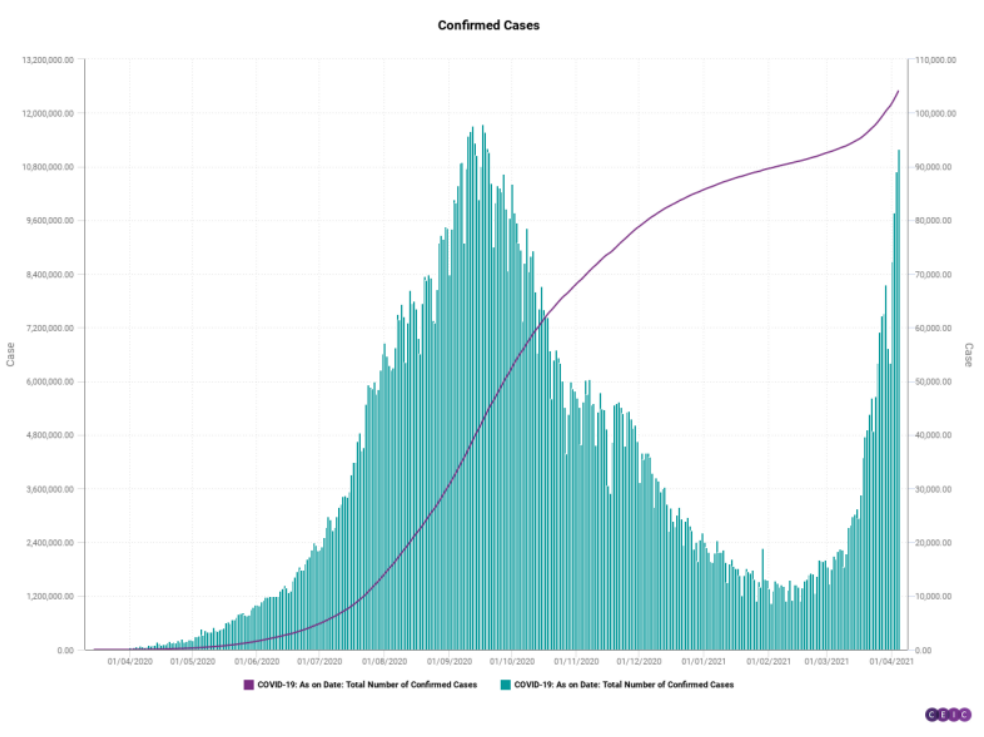

Source: CEIC

COVID-19 has had a significantly adverse impact on the Indian economy as a whole. Be it economic, social or political, COVID-19 has hit India in the worst way possible, With 12.5 million cases, the Indian Economy is still struggling to contain the spread of this virus. It all started on $24^{\text {th }}$ March, when Prime Minister Narendra Modi declared a nation-wide 21 day lockdown in an attempt to control the spread of SARS-CoV-2 in its early stages, which came to be known as the "world's biggest lockdown". During this time there was a complete shutdown of non-essential services. However, the nation-wide lockdown did not end after 21 days, and continued for two more months, post which the state government was given the liberty to extend the lockdown or unlock according to the guidelines issued by the Central Government. Each state had a different approach for opening up the economy, in phases, with some states even continuing with the lowdown. In spite of the government's attempt to control the infection through the imposition of lockdown and their constant attempt to revive the economy, through fiscal and monetary stimulus, the growth of the economy suffered a severe blow. Moreover, the Indian Economy was already in a phase of slowdown with sluggish demand and labour distress,

\footnotetext{
${ }^{3}$ Principles of Epidemiology: Lesson 6, Section 2|Self-Study Course SS1978|CDC. (2016, September 15). Retrieved from https://www.cdc.gov/csels/dsepd/ss1978/lesson6/section2.html
} 


\section{International Journal of Social Science and Economic Research}

ISSN: $2455-8834$

Volume:06, Issue:06 "June 2021"

before it was hit by COVID-19. As a result, this time has proved to be very challenging for India as it's both a health and economic crisis.

COVID-19 has had a significantly adverse impact on the Indian economy as a whole. India now has the third largest case load in the world. Be it economic, social or political, COVID-19 has hit India in the worst way possible. This study deals with the impact of COVID-19 on the different sectors of the Indian Economy and will comparing the past and prevailing figures. It then moves on to the critical analysis of seven major sectors of the Indian economy: namely the agriculture, manufacturing, services, trade, MSMEs, informal and banking sector. Consequently, the next section discusses the policy implication, recommendations and survival strategies for a Post COVID-19 Era. This is followed by the conclusion and further scope of study.

The study will use time series data, over different time periods for different macroeconomic indicators and industry analysis. Both primary and secondary sources of data will be accessed. The primary data will be used to access the importance of digital transformation for micro, small and medium businesses through the use of cross-tabulation. Moreover, this research will focus on seven main sectors; the agricultural sector which employs, more than one- third of the Indian population, the manufacturing sector which accounts for more than $60 \%$ of Indian exports, the service sector which contributes more than 55\% to India's gross value added, the financial sector which contributes $21 \%$ to the Gross Domestic product of India, the trade sector, where the exports of goods and services account for $19.74 \%$ of the GDP while the import of goods and services accounts for $23.64 \%$. Followed by the Informal sector, whose contribution to the Indian Gross Value in agriculture is $97 \%$ and on which the Indian Economy heavily relies. Lastly, the MSMEs which contribute 30\% to India's GDP through its international and domestic trade.

This study will highlight the most affected sectors. This study uses both quantitative and qualitative approach to reach its objective. In addition to this, this study will also help us identify the flourishing industries during the pandemic. This study is important as it provides a framework for any forthcoming health crises or emergencies for developing economies. This is particularly important for a developing nation like India, since India spends around $1 \%$ of its GDP on healthcare, a disappointing number when compared to other nations. The next section will examines the Impact of COVID-19 on the Indian economy through the review of literature.

\section{Review of Literature}

Indian economy had been a victim of economic recession since 2016 after an uncalculated move by the Prime Minister Narendra Modi led government. To dig deeper into this slowdown and the reasoning behind it, Anand and Azad (2019) discussed the causes of a slowdown in the investments and agricultural growth in recent years. They compared the growth rates in 


\section{International Journal of Social Science and Economic Research}

ISSN: $2455-8834$

Volume:06, Issue:06 "June 2021"

agriculture and industry over the past three regimes, UPA- $1^{4}$, UPA-2 and NDA- ${ }^{5}$. Data from the Annual Survey of Industries (ASI) 2017-18, RBI Handbook of Statistics, Department of Food and Public Distribution and CIEC Data was used. Irrefutable evidence is provided indicating a severe slowdown in the investment during the NDA-1 regime. The gross investment ${ }^{6}$ the years showcased that there was a decline from $26.7 \%$ (UPA-1) to $13.6 \%$ (NDA-1). Moreover, agricultural growth fell from $4 \%$ in (UPA-2) to $3 \%$ in (NDA-1), even slipping to $2 \%$ in April-July 2019-20.

Furthermore, the study recognised three indicators for the lack of demand in recent years. Firstly, the declining levels of capacity utilisation ${ }^{7}$ for the three regimes. It was seen that the falling average of capacity utilization during the NDA-1 indicated that while there was a slow rise in the capital stock in this regime, those who had already installed were not getting utilized to their potential. Secondly, total stock of food (rice and wheat) in the central pool had gone up significantly, indicating an excess of 331 lakh tonnes than the requirement in July 2019. Lastly, the state of the credit and liquidity in the economy is calculated through the credit- deposit ratio, suggesting that since 2017 the Indian Banking system is working much below its credit creating capacity. Moreover, three reasons for lack of demand are recognised. The rural distress caused due to low output prices, decrease in government expenditure for agriculture (2015) and Demonetisation (2016). The paper also highlights another reason: wage suppression where the real wage of regular workers declined by $1.7 \%$ in 2017-2018. Lastly the severe increase in inequality, due to increase in the consumption share of top $10 \%$ by $27 \%$ and decrease in the share of consumption and wealth by the rural population, indicated worsening of urban-rural gap.

During this era of slowdown and sluggishness in the consumer demand and spending, the Indian economy was hit by the SARS-CoV-2, which was not only a health emergency but also an economic crisis. Before moving to the impact of COVID-19 on the different sectors of the Indian Economy, it is important to analyze the Pre-COVID-19 scenario alongside COVID-19 scenario. The study by Dev and Sengupta (2020) examines the pre-covid-19 condition of the Indian Economy as a whole, along with its different sectors. They highlighted that GDP in India had been in a downward trend since 2015-16. The GDP growth rate also slowed down to $4.2 \%$ in 2019-20, lowest since 2002-03. Unemployment marked a 45-year high. Private sector investment has been in a downward trajectory since 2015. Urban Consumption has slowed down significantly in Q4 as indicated by high frequency indicators: contraction of growth in sale of

\footnotetext{
${ }^{4}$ United Progressive Alliance

${ }^{5}$ Narendra Modi-led National Democratic Alliance

${ }^{6}$ which is calculated as a percentage of the total stock across

${ }^{7}$ which was calculated by the ratio of net output produced and capital stock in the ASI data set
} 


\section{International Journal of Social Science and Economic Research}

passenger vehicles and consumer durables. Moreover, weak rural demand prevailed as indicated by decrease in motorcycle sales and contraction in consumer non-durable segment.

The overall impact on the different sectors of the Indian economy is briefly discussed. Tapping into the informal sector of the Indian economy, which had already been in a dire state ${ }^{8}$. Furthermore, the banking system of India is struggling to deal with the great losses due to NonPerforming Assets which has severely affected the credit growth in India, due to the heightened risk aversion of the private banks which is expected to worsen even more during the course of the pandemic. The debt market was also a victim of the shock waves since September 2018, when IL\&FS collapsed. Looking at the fiscal health of the economy, the fiscal deficit of the Indian government exceeded its target of 3.5\% of its budget, and stood at $4.6 \%$ in the year 201920. Additionally, this paper also discusses the monetary policies undertaken by the RBI, even though they opened Rs 4 trillion of liquidity through open market operations between October 2018- December 2019, yet there was no effect on the credit growth. An interesting finding was that the growth in agriculture increased from $2.4 \%$ in FY19 to 4\% in FY20. The disruption of supply chains during lockdown, has caused a great loss for Indian farmers, due to wastage of food. The imposition of lockdown was a great shock for about 40-50 million migrants who tried to return to their villages by foot. Since the outbreak of Covid-19, equity markets have reached a new low every day. In a span of one month (March 2020), the panic selling due to the pandemic erased $23 \%$ of the market capitalization of the companies listed on NSE. This paper highlights that the main factors causing disruption in this pandemic are mass movement of migrant workers from the urban region, Lack of financing, Restrictions on International Trade and logistic issues caused due to supply side disruptions.

Similarly, very interesting a research was conducted by Rakshit and Paul (2020). The study mentions that the primary sector, mainly the agricultural sector has suffered a severe blow from the pandemic. The initiation of the lockdown period was in coherence with the harvest of the rabi crop, but due to the absence of the agricultural workers this crop remained intact. Moreover due to the non-operation of businesses like hotels and restaurants there was a lack of demand for raw materials. This study then moves on to the manufacturing industries where the value of inventories held has dropped down significantly, along with many machines remaining idle, due to reduced demand and supply chain constraints. Further diving into this sector, the paper mentions that there is a significant decline in the sale and production of the automobile sector, which is expected to worsen overtime due to depressed income levels. The textile and apparel industry as well as the pharmaceutical and chemical industries have suffered due to the restrictions on exports and imports in India, respectively. Additionally, the study also visits the

${ }^{8}$ Due to two economic shocks: Demonetisation in 2016 and Goods and Services Tax in 2017. 


\section{International Journal of Social Science and Economic Research}

ISSN: $2455-8834$

Volume:06, Issue:06 "June 2021"

impact of this pandemic on India's service sector. Tourism, hospitality and transportation were among the worst affected industries in the service sector, due to the travelling restrictions imposed by the government. On the contrary, the Healthcare segment, which is the focal point during this pandemic, experienced a boom for both public and private hospitals, due to increase in demand from patients infected from the virus. Similarly, the IT segment which has been the backbone for all businesses has seen a significant increase in demand and growth rate. Lastly, in the BFSI segment, there has been an increase in the number of non-performing loans along with operational and technical difficulties. One silver lining that the paper brings forth is the possibility of increased foreign investments in India as some countries want to discontinue their trading relationship with China, which is currently the world's biggest manufacturing hub. The reasons that the study highlights are the advantages India has in terms of transportation network, inexpensive digital communication network and Indian products being more reliable than Chinese products, to name a few, an opportunity India seeks to exploit.

Understanding every topic from an empirical point of view gives valuable insight to investigate further. Moreover it is important to understand the impact of COVID-19 both in the short term and long term. In order to empirically study the impact of Covid-19 on the GDP and different sectors of the Indian economy, Das and Patnaik (2020) conducted a research. They used secondary data from various sources ${ }^{9}$ and applied various statistical tools and techniques to analyze that data and interpret the results. The study emphasizes that the GDP of Indian Economy was already on a downward trend and this pandemic just worsened the scenario, estimating a permanent loss of 4\% in the real GDP of the Indian economy. For the year 2020-21, the GDP growth rate is expected to contract to $1.9 \%$ which will be the lowest after the growth rate in 1991-92 of 1.1.\%. Consequently, the authors describe the demand side impact of this pandemic which has forced people to stay at home, due to the infectious nature of the disease and the lockdown restrictions imposed by the government. The consumption of the Indian economy is majorly impacted. The unemployment rate has significantly risen 6.7\% on 15th March 2020 to $26 \%$ unemployment on 15th April, 2020. The study also looked at the contribution of the major sectors in the economy to India's GDP, where Consumer and Retail business accounted for 18\% (highest), followed by food and agricultural products and transportation and logistics where the latter two are essential commodities. When looking at the impact of Covid-19 on different sectors both in the short term and long term, it is found that in the case of consumer and retail businesses, the short term impact is the slowdown of cash alteration for all categories while the long term impact would be on the demand of non-essential goods which consumers would be reluctant to purchase due to fear of infection. Similarly due to restrictions on domestic and international travel, the Aviation and Tourism sector has been severely impacted, with 'he World

${ }^{9}$ books, articles, internet and public investigations 


\section{International Journal of Social Science and Economic Research}

ISSN: $2455-8834$

Volume:06, Issue:06 "June 2021"

Travel and Tourism Council (2020) estimating that "the crisis will cost the tourism sector at least USD 22 billion, the travel sector shrinking by up to $25 \%$ in 2020, resulting in a loss of 50 million jobs". In the food and agriculture sector, there is low impact on essentials like fruits and vegetables, while supply chain constraints and restrictions on exports to the U.S, China and Europe would have a heavy long term impact. Additionally, other sectors to be severely affected both in the short term and long term are the power, automobiles, transportation and logistics and Telecommunications. Therefore, this outbreak has hit the Indian economy at a time with no preparedness and has caused great ambiguity which the Indian economy is still fighting to revive from.

Some sectors of the India have suffered more than the others, whereas there are some sectors that have experienced a positive impact. Chaudhary, Sodani and Das (2020) focused on discussing the major toll on India's GDP growth rate by analysing the affected sectors, namely, Tourism, Aviation, MSMEs, capital markets, retail and oil. Due to restrictions on travel, both international and domestic, the tourism sector which India is known for and accounts for 9.2 percent of India's GDP will have a negative impact on the growth rate bringing it down by 0.45 percent. They further estimate that revenue from the aviation sector will suffer by USD 1.56 billion. Reaching a 18 year old low, oil prices have reached as low as \$22 per barrel in March 2020. Moreover, since the inception of the Covid-19 pandemic, FPI's ${ }^{10}$ worth USD 571.4 million has been revoked by investors in India to a great extent. There has been a withdrawal of Rs 140.5 billion from the debt market and 247.76 billion from the equity market, in just a span of 13 days. ${ }^{11}$ The GVA ${ }^{12}$ at basic price has decreased by 1.7 percent from 2018-19 to 2019-20. In addition, the sector which has been impacted worst is the construction sector which suffered a decline of $-5.6 \%$ in the growth rate in the same time period. The ongoing Covid-19 crisis has caused the rupee to depreciate consistently. Additionally, due to the imposition of a lockdown overnight, there was a mass departure of migrants from the cities on foot, who were trying to reach their villages, during the time of this crisis, which has led to a labour market shock. Around 92.5 percent of labourers have been a victim of losing 1 to 4 weeks of work. The risk of falling deeper into poverty has increased significantly for about 400 million people, who work in the informal sector of the Indian Economy. The reason for this exodus is considered to be loss of their job, fear of not getting daily ration and absence of a social security net. However this study also mentions that there is a ray of positivity, where India will get more opportunities through organising their global supply chains and inflow of multinationals due to loss of trust in China. Thus successfully

\footnotetext{
${ }^{10}$ Foreign Portfolio Investments

11 (March 1st- March 13th, 2020)

${ }^{12}$ Gross Value Added
} 


\section{International Journal of Social Science and Economic Research}

ISSN: $2455-8834$

Volume:06, Issue:06 "June 2021"

highlighting the positives and negatives of this pandemic is done, which has brought the economic and social life to a standstill and has increased the probability of a global recession.

After looking at the overall impact of COVID-19 on the different sectors, understanding the impact of COVID-19 on every important sector, extensively is crucial for deep understanding of that particular sector. First we look at the Agricultural sector which employs, more than onethird of the Indian population. The impact of the Covid-19 Lockdown on the Agricultural and Rural sector of the Indian Economy is studied by Rawal, Kumar, Verma and Pais (2020). The paper highlights that the unplanned and sudden imposition of the lockdown, caused a massive disruption of the agricultural activities such as purchasing of raw materials, harvesting and sale of the produce. Harvesting of wheat crops suffered a major blow, since the imposition of lockdown was during the harvesting season, there was a shortage of labourers since inter-state movement was not permitted and farmers had to do the work themselves or use local labour. There was a severe slowdown in post-harvest activities like loading, storage and threshing due to the same reason. The study also gave special attention to perishables, where the demand for milk reduced by $20-25 \%$, with the price of procuring milk significantly dropping in several states. Due to the restrictions imposed on exports of goods as well as a huge drop in domestic demand, farmers producing special fruits like mangoes, litchis and melons suffered a major blow. Poultry farmers also suffered major losses due to the rumours regarding bird flu and Covid-19 came into light. Additionally the study also highlights the period between March 1st and April 29th- a period during which around 59\% of the area of India had excess rainfall (which is over 60 percent), which lead to colossal losses of crops. Moreover, lack of storage facilities for perishable fruits and vegetables, caused these crops to rot, leading to enormous losses for the producers of these crops. Furthermore, the imposition of the lockdown did not allow the farmers to take their products to the wholesale market and prevent the traders from going and purchasing the produce from the villages, due to the disruption of the supply chains all over India. The lack of arrangements by the government to control and prevent infections in mandis, caused several mandis to shut down, causing loss of jobs and increased poverty. There was a delay in the procurement of produce by several weeks, with the procurement of chickpea and mustard being negligible, by may $15 \mathrm{th}$. Besides this, there was a halt in the creation of employment through the MGNREGA scheme, therefore the monthly employment creation of April 2020 was not met, just $12 \%$ of what it was projected to be. Therefore the agricultural and rural sector suffered greatly due to the pandemic and the imposition of lockdown, which was a government initiative to control the spread of infection.

Similarly, Sahoo and Samal (2020) also studied the impact of COVID-19 on the Indian Agricultural Industry. With $69 \%$ of the Indian population living in rural areas, it is very important to look at the impact on this sector and discuss the way forward. The study highlights 


\section{International Journal of Social Science and Economic Research}

ISSN: $2455-8834$

Volume:06, Issue:06 "June 2021"

6 major impacts of Covid-19 on the agricultural sector. The first impact being on the rural supply chain disruption, eleven though the government allowed the movement of trucks with essentials, but only if they possessed a permit. Moreover there is a temperate impact on the demand side due to prohibitions on restaurants which has caused huge losses to the farmers. Additionally the railway ministry reported that there has been a significant decline in the freight loading from 10,000 tonnes to 3000-4000 tonnes a day. The second impact being delay in sowing and harvesting of produce which was due to lack of seeds, tractors and drugs and fertilizers for the protection of crops. Moving on to the third impact is the prediction of task cuts in the agricultural sector. The fourth impact, which is one of the most significant one is the complete shut down and restrictions on exports. India is a major exporter of vegetables to many countries, its agricultural exports in 2018-19 stood at Rs 685 billion. Thus, this imposition of a complete lockdown causing shut down of ports has forced the farmers to hold huge stocks with them, which they can no longer export. In addition to these impacts, the MSMEs and SMEs have faced a major sales hit, which has even caused a significant number of people to lose their jobs, without even knowing whether the situation will settle down and go back to normal in the near future. The study mentions that the sixth and final impact of the Covid-19 pandemic would be weak consumption demand in the future. Due to the uncertainty associated with this economic crisis, many people will curtail their spending, till they are ensured job security again also when they have significant savings, thus will change their spending habits. Moreover this will not only be restricted to India but also worldwide, causing a huge toll on manufacturing giants. This uncertainty is even greater in the rural regions which have been distressed by this pandemic. This provides a deeper understanding on how the agricultural sector has been impacted by the pandemic.

After looking at the agricultural sector, it is important to look at the manufacturing sector, which accounts for more than 60 percent of the exports of India. A very interesting article by R. Jayaraman (2020) mentions that the imposition of the lockdown in India has hindered the manufacturing sector which contributes about 20 percent to the GDP of India. The auto industry and unorganized sector was already not at a great position. Next, the author mentions an interesting operations management concept: "Root Beer Game" ${ }^{13}$ Effect, where any happening in the market can hinder the supply chain management with suppliers for a short period of time, tend to overproduce and would lead to discount sales in the medium term hitting profitability significantly. The manufacturing sector has been affected by Covid-19 in several ways. Firstly, due to lower offtake, there was lower production of goods. Producers have no choice but to provide extended periods for deferred payment opportunities, giving longer credit periods is preferred by producers rather than total shutdown of their operations. Due to the government

${ }^{13}$ Supply chain management stimulation 


\section{International Journal of Social Science and Economic Research}

ISSN: $2455-8834$

Volume:06, Issue:06 "June 2021"

directives which allowed only a small number of employees to work, there was a huge impact on the operations, in terms of cost, production volume and quality of products. Over time this leads to negligible turnover for the business. The logistics operations are severely affected with increased risk for their businesses. Furthermore, there is increased monetary risk, due to the slowdown in banking operations which leads to reduced working hours and delayed money transactions due to overloaded communication lines. Finally, there is a postponement of demand by buyers, who refrain from purchasing non-essential items, due to the high level of risk and uncertainty associated with this crisis. The article mentions that the scenario post COVID will be different for every company, those which have superior operational parameters will take off faster than the others. The company's approach in coming out of this crisis is very important for which the author suggests 3 strategies, namely, cost reduction strategy, higher revenue strategy and new products strategy. This would help the companies to improve their profitability ratios by 3 to 4 percent, which is very important for the companies operating in the manufacturing sector.

In order to look at the economic losses and costs associated with the manufacturing industry along with the Net value added, Sahoo and Ashwani (2020) calculated the impact of COVID-19 on the manufacturing sector by using the Annual Survey of Industries data for this sector and computing the economic loss ${ }^{14}$ in the country. In an era without COVID-19 the manufacturing industry would have had a growth rate of about 4.7 percent (NVA) over the benchmark NVA. ${ }^{15}$ After the inception of COVID-19, the economic cost is estimated to range between 5.5\% and $19.8 \%$ depending on the gravity of the situation. With Covid-19, the fall in NVA, when compared to the benchmark period, was largest at $21 \%$ for basic metals and electric equipment, $18 \%$ for textiles, $15 \%$ each for refined petroleum products, coke and motor vehicles. The sectors that add the most value in manufacturing like electronics, motor vehicles and machinery rely heavily on imports and due to supply chain disruptions it's causing the factories to shut down. With Manufacturing contributing to more than $60 \%$ of the Indian exports, the restrictions imposed due to partial or complete lockdown in many countries has severely affected the export segment of India. The paper also mentions the problem of reverse migration that has taken place due to the imposition of the lockdown, which has increased the cost of labour for these industries.

The COVID-19 pandemic has had a huge impact on the international trade, especially the exports of India. Sahoo and Ashwani (2020) mention that two-third of India's exports and imports are from its trading partners USA, China, EU and South-East Asian countries. With all these countries being severely impacted by Covid-19, and the risk of recession rising constantly

${ }^{14}$ Economic loss is computed by using fixed costs and wages, net expenses and interest along with the Net Value Added for that particular industry.

15 (average of the period from 2014-17). 


\section{International Journal of Social Science and Economic Research}

ISSN: $2455-8834$

Volume:06, Issue:06 "June 2021"

for them, even though the value of the Indian rupee has declined, there has been a huge fall in the aggregate demand of the country. To calculate the expected fall in exports and imports, the Global Financial Crisis Figures are taken as the base. The paper assumed a U-shape recovery scenario for India, just as it was in the case of the Global Financial Crisis for all countries, and estimated that there would be $19.8 \%$ fall in exports and $31 \%$ fall in imports for the year 2020 . The reason associated with the fall in imports is the weak and sluggish domestic demand. Moreover, after the inception of Covid-19, there was a significant fall in the exports and imports in the first quarter of 2020 , by $11 \%$ and $9 \%$ respectively. Additionally, the percentage decline in imports and exports is estimated to be the most significant for commodities like machinery, electronics, rubber and plastic. Therefore, the Covid-19 would cause spill over effects affecting the intra-industry trade due to disruption of supply chain.

The integration of global trade and supply chain tends to pose a huge threat to every country in the world. The restrictions imposed to control the spread of this infectious disease will cost the international trade sector significantly, due to negligible exports and imports. A report by UNCTAD (2020) highlighted that due to Covid-19, all the economies around the world will undergo an economic crisis and those that will be most severely affected by Covid-19 are the European Union (EU) by $\$ 15.6$ billion, followed by the United States at $\$ 5.8$ billion, Japan at $\$ 5.2$ billion and South Korea at $\$ 3.8$ billion. The Indian Economy was among the top 15 worst affected economies due to the inception of Covid-19 and the slowdown caused in Chinese production which will cost the Indian economy 348 billion USD. The breakdown of this huge figure showed that the impact on trade was most significant for the chemical industry at \$129 million USD, followed by the textiles and apparel industry which was at \$64 million USD, leather products which was at $\$ 13$ million USD, the automotive industry at \$34 million USD, metal products and metal stood at \$27 million USD and electric machinery at \$12 million USD. Therefore, the Coronavirus which originated from China, not only has a negative impact on China but would be a significant threat of slowing down the global economy, as any slowdown in one part of the world has a severe chain effect for the rest of the world, the UNCTAD estimated a decrease of $\$ 50$ billion in global manufacturing exports in February 2020 alone due to the disruption of the global demand and supply chains.

Apart from the sectors mentioned above, it is important to gain insight into the financial sector which contributes $21 \%$ to the Gross Domestic Product of India. Ernst \& Young (2020) examined the extent and intensity of the impact that Covid-19 has had on the on Indian and global financial markets. As the fiscal year in India concluded on 31st March , 2020 it became essential for assessing the impact on BFSI i.e. Banking, Financial Services and Insurance sector. The central bank had initiated its duty by providing some considerable relief to the country's lending institutions in terms of supervision and regulation, liquidity and functioning of financial 


\section{International Journal of Social Science and Economic Research}

ISSN: $2455-8834$

Volume:06, Issue:06 "June 2021"

markets. With strong relaxations on its credit risk assessment policy i.e. classification as restricted assets or NPA, provisions for moratorium which would help the borrowers resurrect from their financial distress. In order to infuse liquidity throughout the lending institutions RBI reduced the CRR for all banking institutions by 100 points (basis) i.e. $3 \%$ of time liabilities and net demand, substantial reduction in CRR balance from min. $90 \%$ to $80 \%$, increase in the Marginal standing facility from under $2 \%$ to $3 \%$ and widening the policy rate from 50 to 65 basis points in order to achieve stability and ease volatility (short term) in the Indian money markets. These measures would thereby set off the liquidity crunch induced due to the moratorium allowed to the general public, however banking institutions are required to ensure appropriate process for usage of excess funds. As a consequence of global financial disruption business transactions are subject to cancellation and postponement due to lower trading volumes. RBI in discussion with Indian Government ascertained to allow banking institution participation the $\mathrm{NDF},{ }^{16}$ this action serves the long standing demands of industry and removes the bifurcation of onshore and offshore markets leading to better price discovery and forex risk management. The pandemic has significantly impacted the insurers in the terms of balance sheet i.e. liabilities and assets which in turn impacts the future growth and business continuity. Unprecedented uptick in mortality claims had led the insurers' window to be flooded with claims and inquiries putting the system through an acid test of their financial risk management. The ambiguity of claims linked to shutting down of factories and business offices due to occurrence of pandemic may be a potential loss of profit clause for the insurance institutions.

Another insight into the financial sector was India is given by Srinivasan, Karthik and Saggar (2020) from ICRA. They identify and substantiate the impact of the ongoing COVID-19 pandemic on nonbanks, brokerage industry and insurance industry. The first half of the paper focuses on non-banks, with rupees 35 trillion in advances as of 2019. As many of the borrowers i.e. ranging from individual retail to large corporate borrowers are severely impacted by subdued demand and business restrictions imposed this significantly impacts liquidity and cash flow position of these borrowers. Limited funding and inadequacy of credit relations has also affected their debt servicing capabilities. In short the outlook for nonbanks remains negative due to weakened asset quality, solvency and liquidity in the economy. Retail housing loans, small business loans, real estate and construction finance and microfinance loans are the primary underperforming segments for non-banks portfolios. Moving to the brokerage industry which were heavily moved by $31.6 \%$ and $31.8 \%$ respective decline in NIFTY and The Sensex in the month of March. Given the subdued condition of global financial markets, Indian security brokerage industry, which stands at rupees 200 billion as of 2020 was severely impacted by

${ }^{16}$ Non deliverable Forwards market 


\section{International Journal of Social Science and Economic Research}

ISSN: $2455-8834$

Volume:06, Issue:06 "June 2021"

unforeseen sell off by FPI i.e. foreign portfolio investors. ${ }^{17}$ Risk averse investor sentiments and low confidence are strong indicators of muted trading volumes and volatility in turn leading to dull revenue growth and profits in the industry. Under the influential weak capital market environment many activities such as commission on sale of financial assets, incomes from investment banking practices and interest income have come to a halt. Deferment of potential accusation, reduction in market and equity values, funds raising have significantly impacted clients leveraged positions. Hence the sector is more prone to global movements rather than just local dynamics which means that companies need to focus on technology and uninterrupted operations for sustainability. Finally heading to the insurance industry, general insurance companies business outlooks signifies a prospective uptick in profitability for the reinsurance rates globally and for India as well. Nevertheless the claims impact has exponentially grown compared to previous year, primarily due to high share of health portfolios. Since the pandemic has led to an unprecedented increase in hospitalization expenses. If the surge of infections in India continues to grow at the same pace, the expected losses are projected at $130-140 \%{ }^{18}$. Solvency for insurance institutions has also drastically fallen, the same can be attributed to market losses suffered in their equity investments portfolio. In conclusion the net MTM ${ }^{19}$ losses are estimated at rupees 31.8 billion. Therefore the unprecedented impact of claims and market losses will lead to a dual shock on solvency of life insurance companies as well.

After looking at the formal sector of the economy, it is essential to look at the informal sector of the Indian economy on which it heavily relies. Shekar and Mansoor (2020) discuss the impact of Covid-19 on the informal sector of the Indian economy. They examined the share of the informal sector to the gross value added of India for the time periods: 2011-12, 2016-17 and 2017-18. In the agricultural sector the GVA contribution by the informal sector was on an increasing trend from $96.8 \%$ in $2011-12$ to $97.1 \%$ in $2017-2018$. This figure indicates that the existence of the agricultural sector in India depends on the informal sector workers. In the construction sector as well, informal sector workers account for a much higher share of Gross value added at $74.5 \%$ in 2016, while in the manufacturing sector $22.7 \%$ GVA was from informal sector workers. This indicated the significance of the informal sector in the Indian economy. The informal sector was greatly affected by government policies like GST and Demonetisation. Moreover, there is substantial evidence that the formal sector was less affected by demonetisation than the informal sector. (Chandrasekhar and Patnaik, 2017). The authors Shekhar and Mansoor (2020) further mention that the nation-wide lockdown has caused millions of people to be a victim of starvation, hunger and even death. The study further emphasizes on the concept of aversion

\footnotetext{
${ }^{17}$ Net outflow of rupees 0.53 trillion

${ }^{18}$ Net Loss Ratio

${ }^{19}$ Market to market
} 


\section{International Journal of Social Science and Economic Research}

ISSN: $2455-8834$

Volume:06, Issue:06 "June 2021"

activities- actions and behaviours of individuals to prevent themselves from getting infected: such as going out less often and the initial government ban on non-essentials. This hampered both the demand and supply side of the economy; by reduction in production and depressed consumer demand respectively. Due to lack of paid leave in the informal sector, and closure of many businesses, many workers have lost their wages.

Additionally, The informal sector despite being an integral part of the Indian economy has often been mistreated. A study conducted by SEWA (2020) indicated that adopting even small scale measures such as washing hands regularly using soap and maintaining "social distancing" proves to be an impediment in such areas. Some domestic workers in Delhi and Bihar have been given paid leaves whereas some on the other hand continue to go to work. Hence, they are severely concerned about their health but cannot afford to sit at home as their daily bread and butter depends on it. Many factory workers have been shown the door and the demand for autos, rickshaws, cabs, etc. have fallen to unprecedented levels. There has been a complete shutdown of wholesale markets, the supply chain has been disrupted and many traders have not received their payments. Along with the catering and wedding business, the pandemic has taken a major toll on the hospitality industry too. With the high cost of living and a dearth of jobs in various cities, migrant workers have been forced to go back to their native places. In doing so, the risk associated with the spread of the novel coronavirus to villages also increases. Some areas of Uttarakhand and Bihar do not even have proper access to hospitals. In case of an infection, the question of getting proper treatment and medical care does not even come into the picture. However, the spread of the virus has been successfully contained in densely populated slums like Dharavi. The Chief Minister of Delhi has announced that daily wage workers, contract labourers, etc. will receive their salary and has also increased pension funds for the elderly, widowed and disabled. Various economic packages have been approved by the central and state governments in order to support the needy and provide stimulus to the economy. These steps are in the right direction in order to support India's informal sector, which is falling apart.

Finally, moving on to one of the most important sectors: the service sector which contributes more than 55 percent to India's Gross Value Added. Kohli (2020) examined the strong hit witnessed by the services economy of India amidst the COVID-19 pandemic, with a robust jump from one of the remotely affected countries to the 2nd highest cases across the globe India's service sectors stands at one of the worst hit by the COVID-19 crisis. Despite of the fact that PMI i.e. purchases manager's index being a narrow indicator, the figures indicate that the rising frequency of cases and uptick in numbers act as a constant source of public fear directly impacted the demand for services. Consumption is restricted due to the stigma of infection being transmitted through exposure to public places substantially impacting contact intensive service. Lack of government policy support in the Indian Economy seems to be another reason for weak 


\section{International Journal of Social Science and Economic Research}

ISSN: $2455-8834$

Volume:06, Issue:06 "June 2021"

rebound of the sector as compared to other economies witnessing similar numbers of COVID-19 infections. While other Emerging market economies expand their public spending Indian markets have been held back due to inadequacy of fiscal space. The steep decline in growth of services sector of $3.1 \%$ i.e. excluding government services is an understatement as government PADO includes many other services which are not a part of the economy such human health, sporting, recreation etc. The volatility in consumption demand is evident through employment effects i.e. $14 \%$ and $25.2 \%$ of male and female workers engaged in hotel trade and restaurant services. Regardless of the fact that some workers in the services were able to restore their jobs and refrain pay cuts through teleworking many of the people engaged in unorganised services sector will prone to sizable pay cuts and layoffs.${ }^{20}$ The author concludes by throwing lights on the necessary government responses required at the moment that is accurate estimation of COVID19 impact on Indian labour markets and employment figures and reinvestigating the dynamics of infection increase.

Another study by Kumar and Nagrani (2020) showcased and analysed the impact of Covid-19 on the service sector of the Indian economy. Questionnaires, published statistics and interviews were used for this study. The Gross Value added by the service sector as a percentage of the total value added was on an increasing trend; at around 53\% in the FY 2018 and more than 55\% in FY 2020, thereby indicating a positive trend for this sector along with a promising future. First there is a mention of restaurants and hotels which has more than 1.42 crore people employed, $72 \%$ respondents indicated that they no longer wished to dine in restaurants due fear of infection, indicating a sluggish future of the restaurant industry and loss of revenue for the government. This paper then moves on to the transport industry which is a major contributor to the Indian economy. Due to Covid-19, public transports like rails, metros, flights and busses have faced a major slowdown. $84 \%$ of the respondents said that they preferred their private transport rather than travelling in the public transport, leading to the government facing a huge GST deficit. Online mode of Education was not preferred by students but had no other option. One of the biggest sub-sector of the service sector is the recreation sector, the majority of which is still closed. Moreover, due fear of catching the infection $87 \%$ of the respondents would not be comfortable using recreational hubs. Ecommerce usage has increased significantly during the lockdown, with online shopping being used on a regular basis by $48 \%$ respondents, $43 \%$ being first time users, with only $9 \%$ respondents preferring offline mode of shopping. Therefore the impact on the service sector has proved to be bittersweet, with a lot of potential in the near future if appropriate measures are taken.

${ }^{20}$ Sectors such construction, food, hospitality and tourism 


\section{International Journal of Social Science and Economic Research}

ISSN: $2455-8834$

Volume:06, Issue:06 "June 2021"

With online education being the main source of communication for school and colleges during the time of COVID-19, it is important to explore this sub-sector of the services sector. Jena (2020) aims at addressing the measures adopted by the Indian Government in order to revive the education sector, highlight and identify the positive effect of Covid-19 on Indian Education and scrutinize the repercussions of pandemic on the same while putting forward some detailed policy suggestions. As a part of preventive measures and ensuring continuity within the sector CBSE guidelines were revised for taking examinations by maintaining a minimum of 1 meter distance between the student and maximum cap of 24 students in a room. MHRD ${ }^{21}$ also introduced and arranged several portals for online education through Direct home TV, Radios etc whilst implementing digital initiatives such as Diksha, E-pathshala and National Repository of Open Educational Resources (NROER) for secondary education. In the case of Higher education , portals such as Swayam, Swayam Prabha, E-PG Pathshala were also introduced to the sector. On close assessment of the sectors it was found that Indian education was moving closer towards Blended learning, rapid increase of $\mathrm{LMS}^{22}$, robust development in soft copy learning materials , infusion of collaborative skills and greater acceptance for open and distance learning. However, the sudden stagnation of economy had severely hampered the learning process for initial 3 months, consequently affecting employment rates in terms of fresh graduates The Centre for Monitoring Indian Economy estimated on unemployment went up from $8.4 \%$ in march, $23 \%$ in early April there was also a severe impact on global employment opportunity and access to numerous global institutions for education. Maximum and unhindered utilisation of online digital platforms and promotion of Work-From-Home culture can ensure sustainability of Indian education sector. Moreover, the upcoming policies should place far greater importance on diversification of these resources to remote regions of the country for equitable educational opportunities.

Through the review of literature, we gained insight on the Pre COVID-19 and current economic scenarios of all Indian sectors. This study aims to analyse the impact of COVID-19 on seven sectors, namely; agriculture, banking, informal, manufacturing, trade, services and MSMEs through the use of both qualitative and quantitative approach, through application of several economic indicators. The papers discussed above do not provide both a qualitative and quantitative analysis for seven important sectors of the Indian economy by comparing their PreCOVID-19 and prevailing figures, then drawing economic inferences through the analysis. Secondly this paper also utilizes a primary research in order to gain insights on the impact digital transformation has on micro, small and medium enterprises. Lastly, this paper brings into light the recommendations and policy implications for each of the 7 sectors discussed in the study.

${ }^{21}$ Ministry of Human Resource Development

${ }^{22}$ Learning Management systems 
International Journal of Social Science and Economic Research

ISSN: 2455-8834

Volume:06, Issue:06 "June 2021"

\section{Data}

This study analyzes the impact of COVID-19 on various sectors of the Indian economy along with the policy implications for all these sectors. The study focuses on 7 sectors of the Indian economy

1. Agriculture Sector

2. Manufacturing Sector

3. Informal Sector

4. Trade Sector

5. Banking Sector

6. MSMEs

7. Service Sector

In order to successfully and effectively analyze the sectors both primary and secondary data was used.

\section{Primary Research}

In order to understand the reaction of the local economy in the era of Digital transformation a research was conducted with 156 respondents, who were owners of locally owned businesses in India. These owners were interviewed through digital questionnaires, in order to understand their perception towards digitisation and the impact COVID-19 had on their businesses.

\section{Secondary Research}

For assessing the impact on COVID-19 on these seven sectors of the Indian economy, secondary data was used to obtain the Pre-COVID-19 and prevailing figures. Data was obtained for economic indicators like: Purchasing Managers Index, Index of Industrial Production, Trade balance, Sector wise deployment of bank credit, growth in the Issuance of new loans, air traffic, growth in agricultural wages and the growth rate in all seven sectors to name a few. This data was obtained from the Reserve Bank of India Database, The Office of Economic Advisor, CEIC, World Health Organization, news articles, research studies, sector specific annual reports, journals and various government websites. 
International Journal of Social Science and Economic Research

ISSN: 2455-8834

Volume:06, Issue:06 "June 2021"

\section{Methodology}

For the analysis of the seven sectors of the Indian economy, namely, agriculture, informal, manufacturing, services, trade, MSMEs and banking, Microsoft Excel was used to compute the growth rates and absolute values for various economic indicators specific to that particular sector. Consequently, graphs were made for those computed values and trend lines were established. The results were also compared with industry benchmarks in order to determine the performance of that sector, whether it had a positive or negative impact on its functioning. Every analysis and interpretation was also supported by relevant literature from past studies and government reports. This study focuses on 3 parts- Pre-COVID-19 era, COVID-19 era and PostCOVID-19 era.

The next section of this paper is based on a digital questionnaire, where the impact of COVID-19 on local Indian businesses is determined. Respondents were asked to choose 'Yes or No' to the question 'Was your Business affected by the pandemic', then select 'Positive or Negative' for the question 'Impact of the pandemic on your business, followed by the choice between 'Increase and Decrease' for two questions based on their business performance, first being on 'Profitability and Revenue' and 'Scale of operation'. Lastly, the fifth question focused on digitization asking the owners to select either 'Yes or No' for the question- 'Did your business witness digital transformation'. For the analysis, Microsoft excel is used, and trends and connections are determined by using cross tabulations and descriptive data analysis.

\section{Analysis and Interpretation}

\subsection{The Agricultural Sector}

The livelihood of about $58 \%$ of the Indian population depends on agriculture, making it their primary source of livelihood. ${ }^{23}$ Looking at the agricultural sector's real gross value added to the Indian economy, it amounts to around Rs 20.7 trillion in 2018, following a decreasing trend, with reduction of 2 percent in 2018. ${ }^{24}$ Even in Pre-COVID-19 era, there has been considerable rural distress, due to reduced prices of agricultural commodities even below minimum support price, wage suppression, reliance of the country on alternative sectors like manufacturing and services and increased urbanization leading to increase in the urban-rural inequality. Moreover, Demonetisation served a major blow to the agricultural sector. Rural demand in a way is determined by the performance and success of the agricultural sector.

\footnotetext{
23 Agriculture in India: Industry Overview, Market Size, Role in Development...

${ }^{24}$ Agriculture in India - statistics \& facts.
} 
International Journal of Social Science and Economic Research

ISSN: 2455-8834

Volume:06, Issue:06 "June 2021"

Figure 5.1.1: Quarterly growth rates of GDP for Agriculture

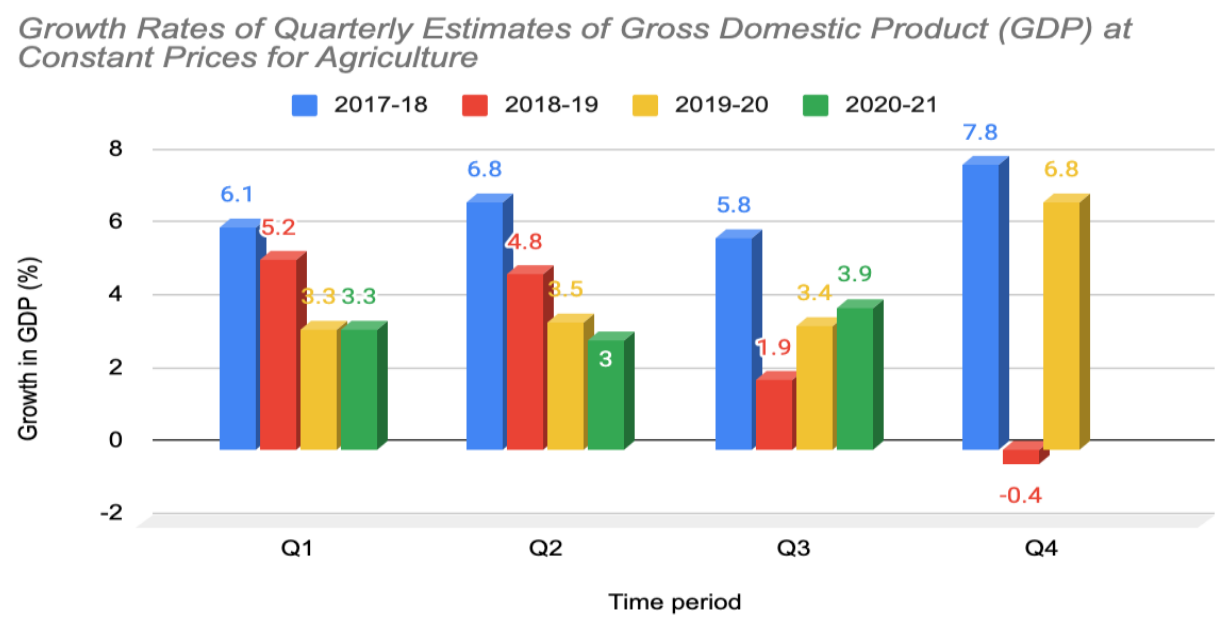

Source: Data derived from Ministry of Statistics and Programme Implementation

However, according to the reports of the Ministry of Statistics and Programme Implementation (MOSPI) as shown in figure 5.1.1, the growth rates for GDP agriculture, decreased for all four quarters from the time period 2017-18 to 2018-19, lowest being -0.4 in Q4 of 2018-19. However, signs of recovery were witnessed in the year 2019-20 with the growth rate increasing to $6.8 \%$ in Q4. Even after the inception of COVID-19, the quarterly figures remained at par with the previous year and even increased in Q3. We can see that the impact of COVID-19 on agricultural sector has not been adverse, with the first three quarters of 2020-21 indicating promising growth rates.

Table 5.1.1: Agricultural Performance Over The Years

\begin{tabular}{|c|c|c|c|c|c|c|}
\hline & \multicolumn{2}{|c|}{ Total Production (In Million Tonnes) } & \multicolumn{3}{|c|}{ Growth Rates } \\
\hline Year & Kharif & Rabi & Total & Kharif & Rabi & Total \\
\hline $\mathbf{2 0 1 5 - 1 6}$ & 125.09 & 126.45 & 251.54 & & & \\
\hline $\mathbf{2 0 1 6 - 1 7}$ & 138.33 & 136.78 & 275.11 & 10.58 & 8.17 & 9.37 \\
\hline $\mathbf{2 0 1 7 - 1 8}$ & 140.47 & 144.55 & 285.02 & 1.55 & 5.68 & 3.60 \\
\hline $\mathbf{2 0 1 8 - 1 9}$ & 141.52 & 143.7 & 285.22 & 0.75 & -0.59 & 0.07 \\
\hline
\end{tabular}


International Journal of Social Science and Economic Research

ISSN: 2455-8834

Volume:06, Issue:06 "June 2021"

\begin{tabular}{|l|l|l|l|l|l|l|}
\hline $\mathbf{2 0 1 9 - 2 0}$ & 143.81 & 153.69 & 297.5 & 1.62 & 6.95 & 4.31 \\
\hline $\mathbf{2 0 2 0 - 2 1}$ & 147.95 & 155.4 & 303.35 & 2.88 & 1.11 & 1.97 \\
\hline
\end{tabular}

Source: Ministry of Agriculture and Farmers Welfare (2021)

Table 5.1.1 exhibits the performance of the agricultural sector in terms of the total production of crops during the two seasons: kharif and rabi. In absolute terms the production of crops is on an increasing trend, even reaching an all-time high of 2020-21 in 2020-21. Even though the growth rates improved drastically in 2019-20, they reduced ub 2020-21, due to the inception of the COVID-19 pandemic, reducing from $4.31 \%$ in $2019-20$ to $1.97 \%$ in $2020-21$.

\section{Figure 5.1.2: Total Agricultural Production (In Million Tonnes)}

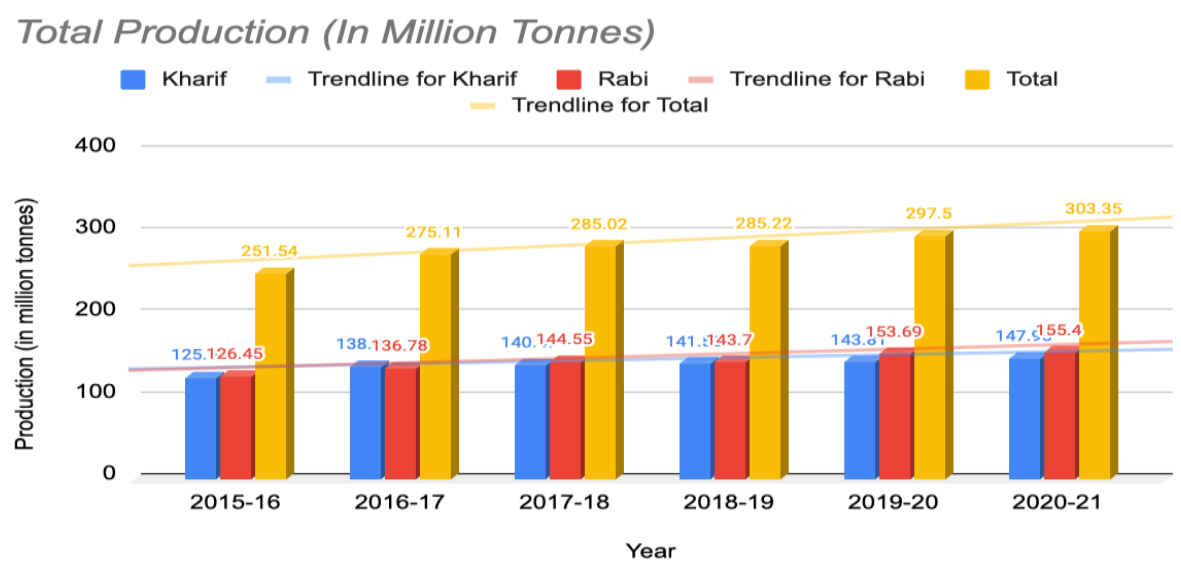

Source: Ministry of Agriculture and Farmers Welfare (2021) 
International Journal of Social Science and Economic Research

ISSN: 2455-8834

Volume:06, Issue:06 "June 2021"

Figure 5.1.3: Growth in Agricultural Production (\%)

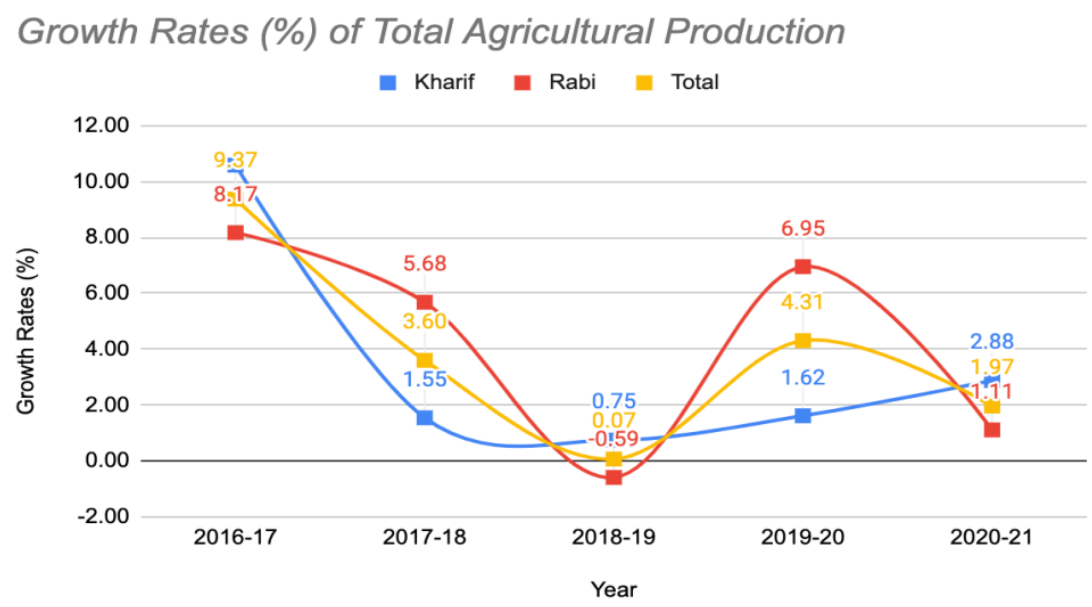

Source: Ministry of Agriculture and Farmers Welfare (2021)

The inception of lockdown 1 in India to control the spread of the virus was in sync with the harvest of the rabi season. This can be seen in Figure 5.1.3, where the growth in the rabi season decreased drastically from $6.95 \%$ in $2019-20$ to $1.11 \%$ in $2020-21$. Several reasons can be attributed to this significant decrease. This took place due to supply chain disruptions like the huge exodus of migrant workers which caused a labour market shortage, forcing the farmers to do all the work themselves, which was very difficult. This caused a slowdown in several postharvest activities as well, namely, storage, threshing and transportation. Even though movement of agricultural transportation vehicles was permitted almost immediately after the inception of lockdown, it was still very hard for the farmers logistically. The lockdown also prevented farmers from traveling to the wholesale mandis to sell their products and earn through exports, leading to great losses for the farmers. The effect of the pandemic was also experienced on the demand side. There was a significant lack of raw materials from hotels and restaurants, with even the domestic demand subdued. These reasons are in accord with the research study by Rawal, Kumar, Verma and Pais (2020).

Table 5.1.2: Growth Rate (\%) of Average Daily Wage Rate for Men in 12 Agricultural Occupations

\begin{tabular}{|c|c|c|}
\hline Period & $\begin{array}{c}\text { Sum of 12 Agricultural Occupations } \\
\text { (Rs) }\end{array}$ & $\begin{array}{c}\text { Growth in wage rate } \\
(\%)\end{array}$ \\
\hline Jan-2016 & 3107.49 & \\
\hline
\end{tabular}


International Journal of Social Science and Economic Research

ISSN: 2455-8834

Volume:06, Issue:06 "June 2021"

\begin{tabular}{|c|c|c|}
\hline Apr-2016 & 3113.67 & 0.20 \\
\hline July-2016 & 3167.53 & 1.73 \\
\hline Oct-2016 & 3295.9 & 4.05 \\
\hline Jan-2017 & 3364.69 & 2.09 \\
\hline Apr-2017 & 3391.81 & 0.81 \\
\hline July-2017 & 3425.08 & 0.98 \\
\hline Oct-2017 & 3450.08 & 0.73 \\
\hline Jan-2018 & 3135.8 & -9.11 \\
\hline Apr-2018 & 3171.57 & 1.14 \\
\hline July-2018 & 3509.36 & 10.65 \\
\hline Oct-2018 & 3597.98 & 2.53 \\
\hline Jan-2019 & 3599.78 & 0.05 \\
\hline Apr-2019 & 3627.57 & 0.77 \\
\hline July-2019 & 3672.66 & 1.24 \\
\hline Oct-2019 & 3681.9 & 0.25 \\
\hline Jan-2020 & 3752.31 & 1.91 \\
\hline Apr-2020 & 3862.06 & 2.92 \\
\hline July-2020 & 3903.33 & 1.07 \\
\hline Oct-2020 & 3870.57 & -0.84 \\
\hline
\end{tabular}

Source: Data derived from Reserve Bank of India (2021)

Table 5.1.2 exhibits the growth rate for daily wage in the summation of twelve agricultural occupations $^{25}$ for men, indicating that the growth rate has been almost insignificant over the years, in fact in absolute terms, the wages have been on an increasing trend, even though the extent of increase is not that significant.

${ }^{25}$ Notes on Table RBI 
International Journal of Social Science and Economic Research

ISSN: 2455-8834

Volume:06, Issue:06 "June 2021"

Figure 5.1.4: Growth Rate (\%) of Average Daily Wage Rate for Men in 12 Agricultural Occupations

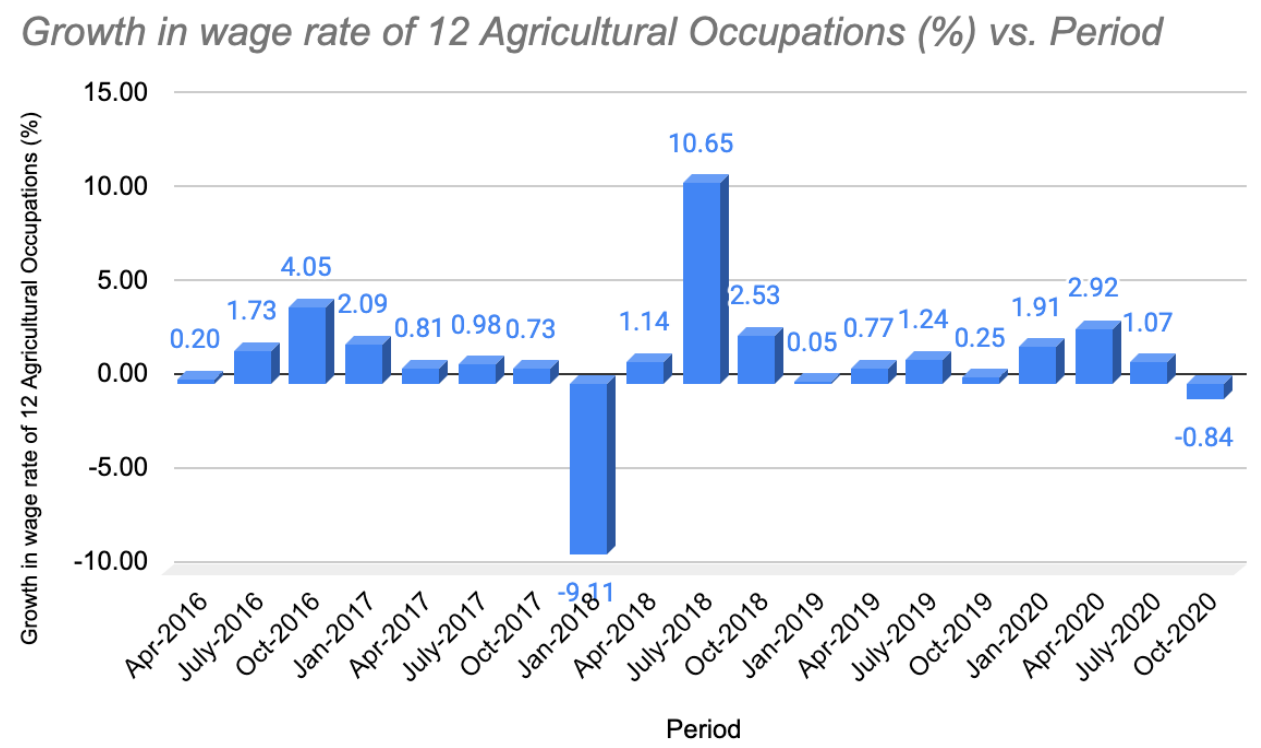

Source: Data derived from Reserve Bank of India (2021)

It can be seen in Figure 5.1.4 that the growth rate has been on the lower side since the Q4 of 2018, with the lowest being in Q4 of 2020 at $-0.84 \%$ where the growth rate was actually on the lower side. This coincided with the rural unemployment rates even soaring to $17.92 \%$ in June $2020 .{ }^{26}$ Poultry farmers were also affected in states like Maharashtra, Odisha, Andhra Pradesh and Karnataka due to the spread of false rumours that chickens are carriers of COVID-19. ${ }^{27}$ Therefore, it can be noted that even though agricultural products come under essential goods, the lockdown temporarily had a negative impact on this sector, due to several supply side, demand side and labour constraints and disruptions. A positive ray of light being that this sector has already witnessed promising recovery.

\subsection{The Informal Sector}

India is home to the largest informal sector in the world. According to the Government of India Statistics, the informal sector embodies nearly 90 percent of the Indian workforce contributing

\footnotetext{
${ }^{26}$ Rural unemployment rate falls to $17.92 \%$, lowest since lockdown

27 The Govt Must Quickly Act to Counter the Wild Rumours Killing the Poultry Sector
} 
almost 50 percent to the total GDP of the country. ${ }^{28}$ The informal sector has never experienced a smooth journey, instead has been a victim of several government economic policies that have done more harm than good to its sector. This sector was severely affected by the Demonetisation (2016) and The Goods And Services Tax (2017) policy reforms (Shekar and Mansoor, 2020). The poor implementation of both of these policies backfired for the Indian Economy. During demonetisation a large number of businesses went out of business as they heavily depended on cash and hence suffered severe losses and became bankrupt. It is proved that the informal sector was more severely affected by demonetisation than the formal sector of the Indian economy (Agrawa, 2018; Chandrasekhar and Patnik, 2017). Infact, about 6.18 million jobs were lost during 2012-18, for which GST and demonetisation is responsible (Kannan and Raveendran, 2019). Thus, it is safe to say that the informal sector has experienced a turbulent journey over the last 5 years.

Table 5.2.1: Sector-wise trends of formal and informal sector employment in India, 20052018

\begin{tabular}{|c|c|c|c|c|c|c|c|c|c|c|}
\hline \multicolumn{10}{|c|}{ Sector-wise trends of formal and informal sector employment in India, 2005-2018 (in \%) } & \\
\hline & \multicolumn{2}{|c|}{ Manufacturing } & \multicolumn{2}{|c|}{ Non-Manufacturing } & \multicolumn{2}{|c|}{ Service } & \multicolumn{2}{|c|}{ Non-Farm } & \multicolumn{2}{|c|}{ Total Employment } \\
\hline Period & Formal & Informal & Formal & Informal & Formal & Informal & Formal & Informal & Formal & Informal \\
\hline $2004-05$ & 10.4 & 89.6 & 7.2 & 92.8 & 19.2 & 80.8 & 14.8 & 85.2 & 6.2 & 93.8 \\
\hline 2011-12 & 10.9 & 89.1 & 5.3 & 94.7 & 19.9 & 80.1 & 14.4 & 85.6 & 7.5 & 92.5 \\
\hline $2017-18$ & 15.4 & 84.6 & 5.2 & 94.8 & 21.5 & 78.5 & 16.5 & 83.5 & 9.3 & 90.7 \\
\hline
\end{tabular}

Source: International Labour Organization (2019)

Table 5.2.1 shows the trends of informal sector employment over three different time periods. It can be seen that for the Manufacturing sector the informal employment has followed a decreasing trend with it being $89.6 \%$ in $2004-05$ to $84.6 \%$ in $2017-18$. Similarly, the informal sector employment has been on a decreasing trend for the service sector and the Non-farm sector, reaching record lows over a period of 14 years at $78.5 \%$ and $90.7 \%$ respectively. On the other hand, in the non-manufacturing sector, the informal sector employment has been on an increasing trend and has even peaked at an all-time high of 94.8\% from 2017-18. Comparing the

${ }^{28}$ What is it that ails our informal sector? 
International Journal of Social Science and Economic Research

ISSN: 2455-8834

Volume:06, Issue:06 "June 2021"

informal sector with the formal sector employment, there is a vast disparity between the two, indicating that the Indian economy heavily relies on the informal sector. This is of uttermost importance as during a policy implementation, the needs of this section of workforce should be taken into consideration.

It's evident that the informal sector suffered much more than the formal sector, with the inception of the COVID-19 pandemic and the several lockdowns aimed at controlling it. In fact, a recent report, the International Labour Organizations Global Wage Report highlights that while the formal sector experienced a 3.6 percent cut in the wage rate, the informal sector on the other hand was a victim of a much larger wage cut- a stark 22.6 percent. Moreover, the report also brought forth an unpleasant finding that around 40 lakhs to 6.94 crore workers were at a a risk of losing their jobs, during the first two lockdowns in India. Moreover, daily wage labourers and small scale traders lost around 91 million jobs (CMIE) ${ }^{29}$.

India is home to 40-50 million migrant ${ }^{30}$ workers who work for labour intensive jobs like construction in urban areas, road construction and even factories to name a few. These jobs were shut down for months since the inception of the pandemic. With no jobs and with the introduction of the first lockdown, migrant workers took upon themselves to travel to their villages by foot, since transport was closed and they couldn't afford to live in the urban areas without a job anymore, let alone feed their family. This led to a huge exodus of migrant workers from the urban to rural areas, many of which are still suffering the negative consequences of COVID-19. It will take the economy a considerable amount of time to get its informal sector back on its feet, creating uncertainty for the informal workers and their families for a while along with even forcing certain informal businesses to shut down during the pandemic.

\section{3 The Trade Sector}

India's trade sector has a significant impact on its GDP growth rate as well as facilities increase of the per capita income (IBEF, 2021). In fact in December 2020, foreign exchange reserve of India stood at Rs 42.75 trillion according to the Reserve Bank of India. Over the years, India has welcomed international trade, following a path of progressiveness. In the year 2019, International trade contributed 40 percent to India's GDP, evidently stating its importance for the Indian economy.

${ }^{29}$ CMIE.

${ }^{30}$ Dev and Sengupta (2020) 
International Journal of Social Science and Economic Research

ISSN: 2455-8834

Volume:06, Issue:06 "June 2021"

Table 5.3.1: Foreign Trade (in \% of GDP) over the years

\begin{tabular}{|c|c|c|c|c|c|}
\hline Indicator & 2015 & 2016 & 2017 & 2018 & 2019 \\
\hline $\begin{array}{c}\text { Foreign Trade (in\% of } \\
\text { GDP) }\end{array}$ & 41.9 & 40.1 & 40.7 & 43.4 & 40 \\
\hline
\end{tabular}

Source: World Bank (2020)

According to the forecast stated by IMF Foreign Trade, in 2020 the volume of exports of goods and services decreased by $10.9 \%$ and the volume of imports of goods and services decreased by 17.4\%. The reason for this plunge is attributed to the COVID-19 pandemic. Decrease in domestic demand for crude oil, industrial products and gold caused the decrease in imports. While the stark reduction in exports was due to decrease in demand for jewellery, textiles and clothing. ${ }^{31}$

\section{Table 5.3.2: India's Foreign Trade}

\begin{tabular}{|c|c|c|c|}
\hline \multicolumn{4}{|c|}{ India's Foreign Trade (Rupees Crore) } \\
\hline Period & Exports & Imports & $\begin{array}{c}\text { Trade } \\
\text { Balance }\end{array}$ \\
\hline Jan:2019-20 & 25832.5 & 41143.9 & -11681.1 \\
\hline Feb:2019-20 & 27729.4 & 37501.5 & -11774 \\
\hline Mar:2019-20 & 21375.7 & 31165.4 & -12778.8 \\
\hline Apr:2019-20 & 26037.7 & 42387.3 & -6847 \\
\hline May:2019-20 & 29849.7 & 46683.4 & -3097.5 \\
\hline Jun:2019-20 & 25027.3 & 41032.5 & 793.2 \\
\hline Jul:2019-20 & 26332.6 & 39759.7 & -4826.3 \\
\hline
\end{tabular}

${ }^{31}$ Foreign trade figures of India - Economic and Political Overview 
International Journal of Social Science and Economic Research

ISSN: 2455-8834

Volume:06, Issue:06 "June 2021"

\begin{tabular}{|c|c|c|c|}
\hline Aug:2019-20 & 25987.9 & 39852.1 & -16349.6 \\
\hline Sep:2019-20 & 26013.7 & 37694.8 & -16833.6 \\
\hline Oct:2019-20 & 26212.4 & 37986.4 & -16005.1 \\
\hline Nov:2019-20 & 25744.5 & 38523.2 & -13427.1 \\
\hline Dec:2019-20 & 27096.1 & 39594.1 & -13864.1 \\
\hline Apr:2020-21 & 10271.4 & 17118.4 & -12498.1 \\
\hline May:2020-21 & 19103.8 & 22201.3 & -15311.4 \\
\hline Jun:2020-21 & 21907.6 & 21114.4 & -9772.1 \\
\hline Jul:2020-21 & 23642.9 & 28469.1 & -9789 \\
\hline
\end{tabular}

Source: Reserve Bank of India (2021)

Figure 5.3.1 \& 5.3.2: India's Foreign Trade (In Rupees Crore)
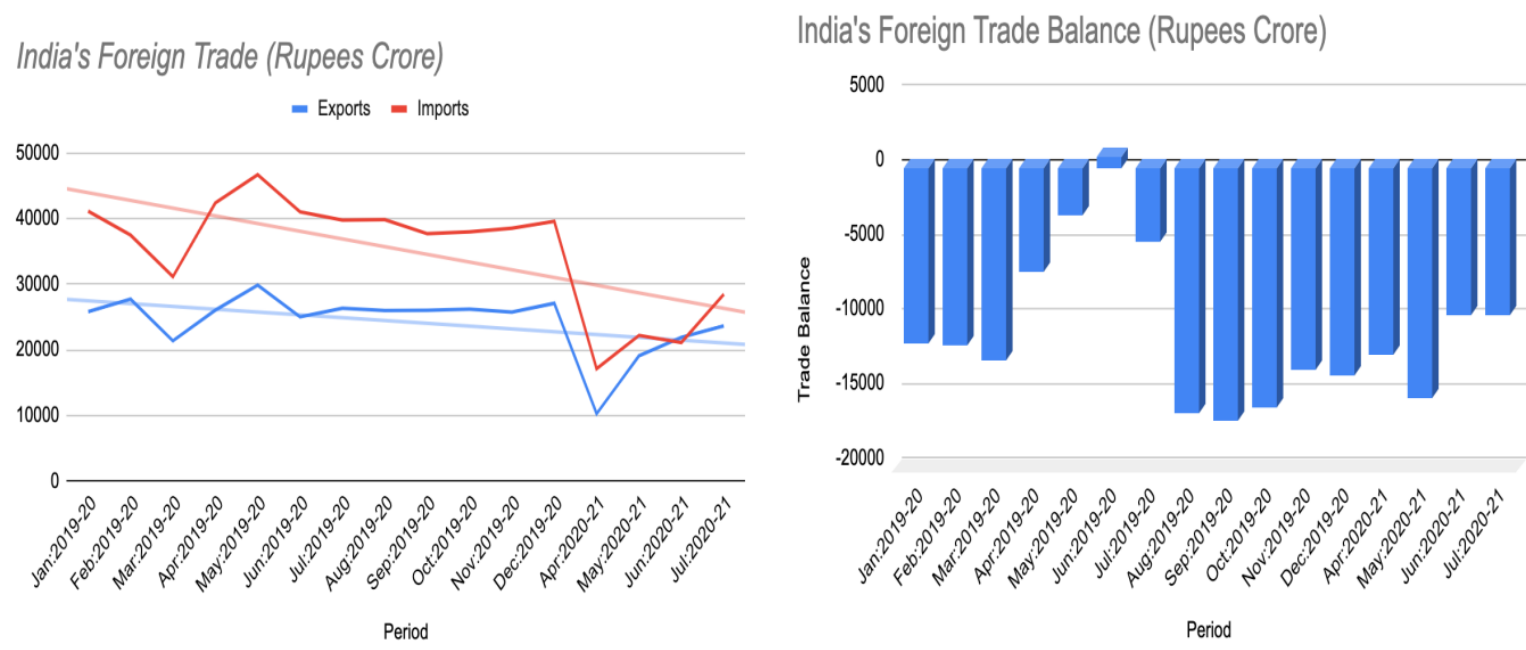

Source: Data derived from Reserve Bank of India (2021)

India's trade balance is naturally low, due to the fact that it relies heavily on imports for its energy source- about 80 percent of its energy needs are met by imports. India's trade balance was positive in June 2019-20, post which India's trade deficit was on an increasing trend. The 
trade balance of India again suffered a severe blow during the imposition of lockdown and the restrictions imposed on international trade as a result of it. As visible in figure 5.3.1 and 5.3.2, from April- june 2020-21, there is a significant plunge in the exports, imports and trade balance. With the lowest exhibited in the month of April 2020, where exports stand at Rs 10,271.4 Crores and imports at Rs 17,118.4 Crores, both numbers being a significant decrease from the previous month. This percentage decline in exports and imports is most serious for commodities like plastic, electronics, machinery and rubber (Sahoo and Ashwani, 2020). Even the countries that are major trading partners of India, namely the United States, China, European Union and even the United Arab Emirates, were severely affected by the virus, hence, causing restriction on trade on both ends. Exports and imports reduced significantly during the peak lockdown period: April, May and June 2020, which had a significant consequence on the volume of trade. According to OECD, India is the worst affected country by COVID-19, with the real GDP in Q4 of 2021 is expected to fall by 7.8 percent. ${ }^{32}$ However, India's trade sector has started showing signs of recovery with its exports growing by $16.2 \%$ year on year in the first week of January. ${ }^{33}$

\subsection{The MSMEs}

The MSMEs which include micro, small and medium enterprises have gained significant importance due to their major contribution to the socio-economic development of the country. It contributes almost 30 percent to GDP of India through its domestic and international trade (IBEF, 2021). Although the number of MSMEs increased by $18.5 \%$ from 2019 to 2020, still there are about only 15 percent of MSMEs that are actually registered. ${ }^{34}$ According to a 2018 IFC report, only 16 percent of MSMEs use the formal banking system for funding, rest rely on informal sources or even self-finance. MSMEs has proved to be significant in terms of the gross value added to the Indian economy. Its contribution to Indian GVA has been on an increasing trend since 2014, reaching 33.5\% in the year 2018-19.

\section{Table 5.4.1: Share of Gross Value Added (GVA) of MSME in all India GDP (Rs Crore)}

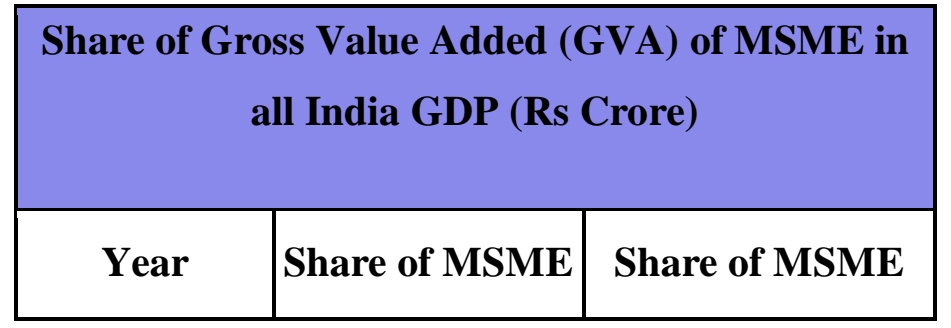

\footnotetext{
32 Indian economy to be hardest hit by Covid-19 despite recovery, predicts new OECD report

33 Indian exports show signs of revival, up $16.2 \%$ to $\$ 6.2$ bn in Jan first weeks

34 MSMEs: Structural issues go beyond the standard challenges
} 
International Journal of Social Science and Economic Research

ISSN: 2455-8834

Volume:06, Issue:06 "June 2021"

\begin{tabular}{|c|c|c|}
\hline & in GVA (\%) & $\begin{array}{c}\text { Iin All India GDP } \\
(\%)\end{array}$ \\
\hline $2014-15$ & 31.8 & 29.34 \\
\hline $2015-16$ & 32.28 & 29.48 \\
\hline $2016-17$ & 32.24 & 29.25 \\
\hline $2017-18$ & 32.79 & 29.75 \\
\hline
\end{tabular}

Source: MSME Annual Report 2020-21

When it comes to credit deployment from banks to the MSME businesses, there has hardly been any growth rate, in fact it has been on the lower side. MSMEs were significantly impacted by Demonetisation and GST (Dev and Sengupta, 2020), since majority of these businesses rely on cash. The MSMEs need credit to stay afloat, even though they use informal means most of the time, when they require loans from the formal financial system the banks prove to be of little to no help. This forces these enterprises to shut their business operations due to lack of working capital. As it can be seen in table 5.4.2, the YoY growth for micro and small enterprises has been negligible, with it being negative in Mar 17 at $-0.5 \%$ and only increasing to $1.7 \%$ in Mar 20 . The provisional estimates of Nov-20 indicate a much lower growth rate from the year before, from $1.7 \%$ to $0.5 \%$. These are disappointing numbers since $99.92 \%{ }^{35}$ MSMEs are dominated by micro and small enterprises, but receive almost no financial support.

Table 5.4.2: Growth in Industry Wise Deployment of Bank Credit by Major Sectors (\%)

\begin{tabular}{|c|c|c|c|c|c|}
\hline \multicolumn{6}{|c|}{ Growth in Industry Wise Deployment of Bank Credit by Major Sectors (YoY, per cent) } \\
\hline Sector & Mar-17 & Mar-18 & Mar-19 & Mar-20 & Nov-20* \\
\hline Micro \& Small & -0.5 & 0.9 & 0.7 & 1.7 & 0.5 \\
\hline Medium & --8.7 & -1.1 & 2.6 & -0.7 & 20.9 \\
\hline
\end{tabular}

Source: Economic Survey of India 2020-21

${ }^{35}$ India's MSME sector swells, adds these many enterprises in FY20; micro businesses dominate 
Looking at the trend for deployment of bank credit for medium enterprises, the growth rate has been following a decreasing trend, with the rate being -8.7 percent in Mar-2017, although the growth rate turned positive in Mar-19, it again turned negative standing at -0.7 percent in Mar 2020. However, the provisional estimates for Nov 20 indicate a promising growth standing at 20.9\%. That said, this does not mean that MSMEs are getting benefitted, since majority MSMEs are small and micro businesses.

\subsection{The Service Sector}

The service sector is a dominant sector in the Indian economy, which has contributed $55.39 \%$ to the Gross Value Added of the Indian economy (IBEF, 2021) and has created significant employment. India's service sector comprises several businesses like hotels, restaurants, construction, transport, business services, communication and personal services to name a few. In the year 2020-21 the service sector excluding construction contributed $54.3 \%$ to GVA. Although the growth in the service sector followed an increasing trend from 2018-20, with the inception of the pandemic, the quarterly growth rates declined severely even reaching $-20.6 \%$ in Q1 of 2020-21, even the growth in H1 of 2020-21 was negative at 2020-21. The reason for this would be the lockdown restrictions imposed by the government.

Table 5.5.1: Performance of the Service Sector

\begin{tabular}{|c|c|c|c|c|c|c|c|}
\hline \multicolumn{8}{|c|}{ Performance of the Service Sector } \\
\hline & \multicolumn{7}{|c|}{ Share in GVA (\%) and Growth percentage } \\
\hline Sector & 2020-21 & 2018-19 & 2019-20 & $\begin{array}{c}\text { 2020-21 } \\
\text { (AE) }\end{array}$ & $\begin{array}{c}\text { 2020-21 } \\
\text { (H1) }\end{array}$ & $\begin{array}{c}\text { 2020-21 } \\
\text { (Q1) }\end{array}$ & $\begin{array}{c}\text { 2020-21 } \\
(\mathbf{Q})\end{array}$ \\
\hline $\begin{array}{c}\text { Trade, hotels, } \\
\text { transport, } \\
\text { communication } \\
\text { \& services } \\
\text { related to } \\
\text { broadcasting }\end{array}$ & 15.4 & 7.7 & 3.6 & -21.41 & -31.5 & -47 & -15.6 \\
\hline Financial, real & 22.2 & 6.8 & 4.6 & -0.82 & -6.8 & -5.3 & -8.1 \\
\hline
\end{tabular}


International Journal of Social Science and Economic Research

ISSN: 2455-8834

Volume:06, Issue:06 "June 2021"

\begin{tabular}{|c|c|c|c|c|c|c|c|}
\hline $\begin{array}{c}\text { estate \& } \\
\text { professional } \\
\text { services }\end{array}$ & & & & & & & \\
\hline $\begin{array}{c}\text { Public } \\
\text { administration, } \\
\text { defence \& other } \\
\text { services }\end{array}$ & 16.7 & 9.4 & 10 & -3.68 & -11.3 & -10.3 & -12.2 \\
\hline $\begin{array}{c}\text { Total Services } \\
\text { (Excluding } \\
\text { construction) }\end{array}$ & 54.3 & 7.7 & 5.5 & -8.8 & -15.9 & -20.6 & -11.4 \\
\hline
\end{tabular}

Source: India budget Service Sector Report 2021

The Purchasing Managers Index for the service sector followed a stable range in the PreCOVID-19 era, Since the index was above 50 for most of the years, it indicates expansion of that sector. However, when India was hit by the COVID-19 pandemic and the lockdown was imposed, in April 2020, the PMI index fell down considerably standing at 5.4 percent indicating severe contraction in this sector. 
International Journal of Social Science and Economic Research

ISSN: 2455-8834

Volume:06, Issue:06 "June 2021"

Figure 5.5.1: Purchasing Managers Index (PMI), Services

Purchasing Managers Index (PMI), Services

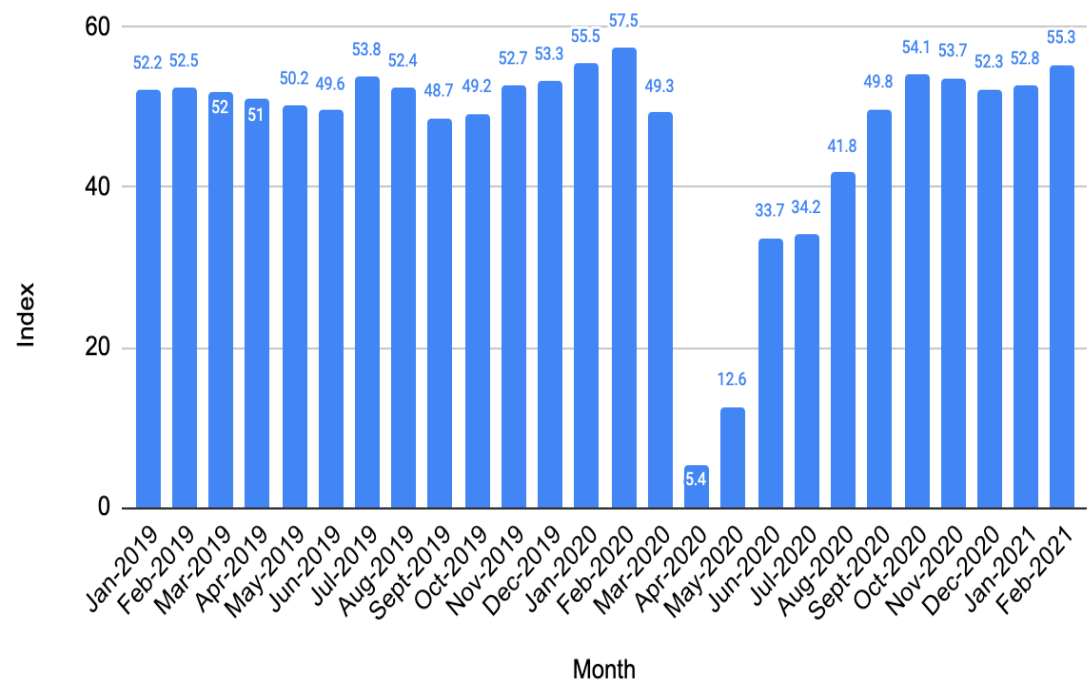

Source: The Global Economy (2021)

Moving on to one of the most important sub-sector of the service sector, Tourism and Travel. This sub-sector suffered a major blow, with the lockdown and imposition of travel restrictions. The foreign Tourist arrivals were severely affected and decreased from 11 million in 2019 to 3 million in 2020, even though it was following an increasing trend from 2016-2019, with the sector booming. 
International Journal of Social Science and Economic Research

ISSN: 2455-8834

Volume:06, Issue:06 "June 2021"

Figure 5.5.2 \& 5.5.3: Foreign Tourist Arrivals (MN) \& Foreign Exchange earnings from Tourism (US \$BN)
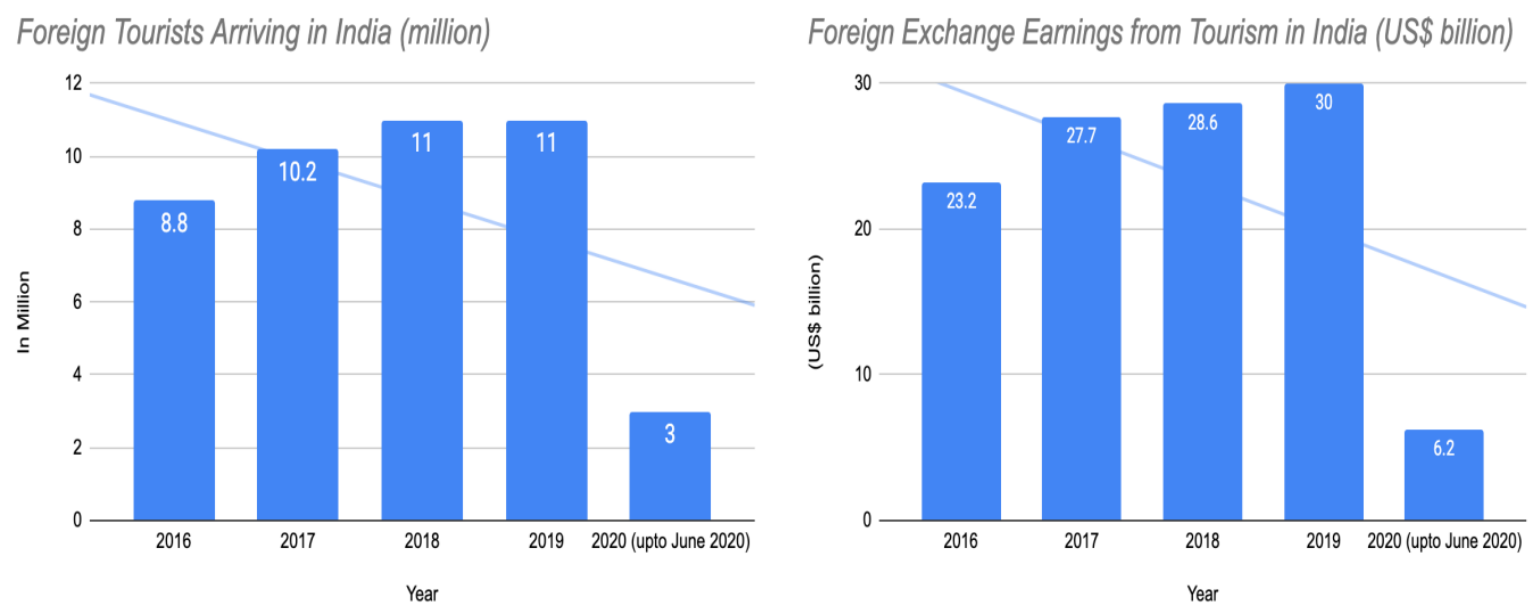

Source: Ministry of Tourism

The foreign exchange earnings from tourism experienced a major downfall from it being USD 30bn in 2019 to USD 6.2bn in 2020 (upto June 2020), even though it's just half the year, it is significantly on the lower side indicating the sufferance of the tourism sector.

Table 5.5.2: India's Passenger Traffic: All Airports (in million)

\begin{tabular}{|c|c|}
\hline \multicolumn{2}{|c|}{ India's Passenger Traffic: All Airports (In million) } \\
\hline Month & $\begin{array}{c}\text { Passenger Traffic (in } \\
\text { MN) }\end{array}$ \\
\hline Mar 2020 & 17.54 \\
\hline Apr 2020 & 0.06 \\
\hline May 2020 & 0.72 \\
\hline June 2020 & 4.25 \\
\hline July 2020 & 4.59 \\
\hline Aug 2020 & 6.16 \\
\hline
\end{tabular}




\begin{tabular}{|c|c|}
\hline Sep 2020 & 8.45 \\
\hline Oct 2020 & 11.17 \\
\hline Nov 2020 & 13.57 \\
\hline Dec 2020 & 15.79 \\
\hline Jan 2021 & 16.73 \\
\hline Feb 2021 & 16.87 \\
\hline
\end{tabular}

Source: CEIC, 2021

The Indian Passenger Traffic for all Indian airports suffered deeply with the imposition of lockdown, with only 0.06 Mn passenger traffic in April 2020, following a similar case in May 2020. However, in February 2021 the passenger traffic stood at 16.87 million passengers almost similar to the levels in March 2020. Still, there is a long way to go for India's travel and tourism sector to bounce back, especially since international travel is still restricted. The quarantine rules and regulations are not feasible in many cases, thus having a huge impact on air traffic on Indian airports.

\subsection{The Banking Sector}

The banking sector of a country is the backbone of any economy, it is the sector that ensures credit flow in the country. During an economic crisis, the actions taken by this sector help address the economic challenge at hand. India's banking sector has been broken for quite a long time, public sector banks are facing massive losses arising from an increase in the nonperforming assets. COVID-19 hit the Indian economy when it was already in a phase of slowdown (Anand and Azad, 2019).

Table 5.6.1: Growth in Sector Wise Deployment of Bank Credit

\begin{tabular}{|c|c|c|c|c|c|}
\hline \multicolumn{7}{|c|}{ Growth in Sector Wise Deployment of Bank Credit (\%) } \\
\hline Period & Agriculture & Industry (Micro & & \\
(Outstanding & \& Allied & \& Small, & Services & Personal & \\
as on) & Activities & Medium and & $(\%)$ & Loans (\%) & Priority Sector (\%) \\
\hline
\end{tabular}


International Journal of Social Science and Economic Research

ISSN: 2455-8834

Volume:06, Issue:06 "June 2021"

\begin{tabular}{|c|c|c|c|c|c|}
\hline & $(\%)$ & Large $)(\%)$ & & & \\
\hline 20 Jan 2017 & -1.07 & -0.69 & 0.47 & 1.29 & -1.44 \\
\hline 28 Apr 2017 & 5.41 & 1.47 & 3.07 & 5.88 & 4.76 \\
\hline 21 Jul 2017 & 0.45 & 0.13 & -0.58 & 3.25 & -0.79 \\
\hline 27 Oct 2017 & 0.69 & -1.10 & 6.25 & 4.74 & 1.04 \\
\hline 19 Jan 2018 & 2.63 & 0.62 & 4.00 & 4.81 & 2.38 \\
\hline 27 Apr 2018 & 1.99 & 1.37 & 9.89 & 5.06 & 2.33 \\
\hline 20 Jul 2018 & 1.13 & -0.53 & 1.32 & 1.21 & 1.59 \\
\hline 26 Oct 2018 & 2.04 & 2.24 & 9.99 & 4.84 & 2.71 \\
\hline 18 Jan 2019 & 2.21 & 2.00 & 1.18 & 4.83 & 2.45 \\
\hline 26 Apr 2019 & 2.29 & 3.10 & 3.63 & 4.01 & 2.45 \\
\hline 19 Jul 2019 & 0.09 & -1.30 & -0.09 & 2.37 & -0.47 \\
\hline 25 Oct 2019 & 2.32 & -0.41 & 1.71 & 5.02 & 1.81 \\
\hline 31 Jan 2020 & 1.65 & 1.10 & 3.38 & 4.50 & 0.22 \\
\hline 24 Apr 2020 & -0.18 & 2.37 & 5.85 & 2.26 & 4.52 \\
\hline 31 Jul 2020 & 1.56 & -2.19 & -1.05 & -0.88 & -2.38 \\
\hline 23 Oct 2020 & 4.23 & -2.89 & 1.15 & 3.17 & 3.60 \\
\hline
\end{tabular}

Source: Reserve Bank of India (2021)

As exhibited in Table 5.6.1, over the months the growth in bank credit deployment has increased for the agricultural and allied sectors, reaching an all-time high of $4.23 \%$. However, there is a huge decrease in the growth rate for industries (micro, small, medium and large), reaching an alltime low of $-2.89 \%$ on 23rd October, 2020, following a downward trend. In the case of the service sector, the growth rates decreased in July 2020 to $-1.05 \%$, however, it is on a really slow path of recovery, reaching $1.15 \%$ in October 2020. For personal and priority loans, the growth in bank credit deployment stood at an all-time low of $-0.88 \%$ and $-2.38 \%$ in October 2020 for the 
International Journal of Social Science and Economic Research

ISSN: 2455-8834

Volume:06, Issue:06 "June 2021"

two sectors respectively. The downward trend of growth in credit deployment is further reinstated through the graphs below.

Figure 5.6.1 \& 5.6.2: Growth in Sector wise deployment of bank credit

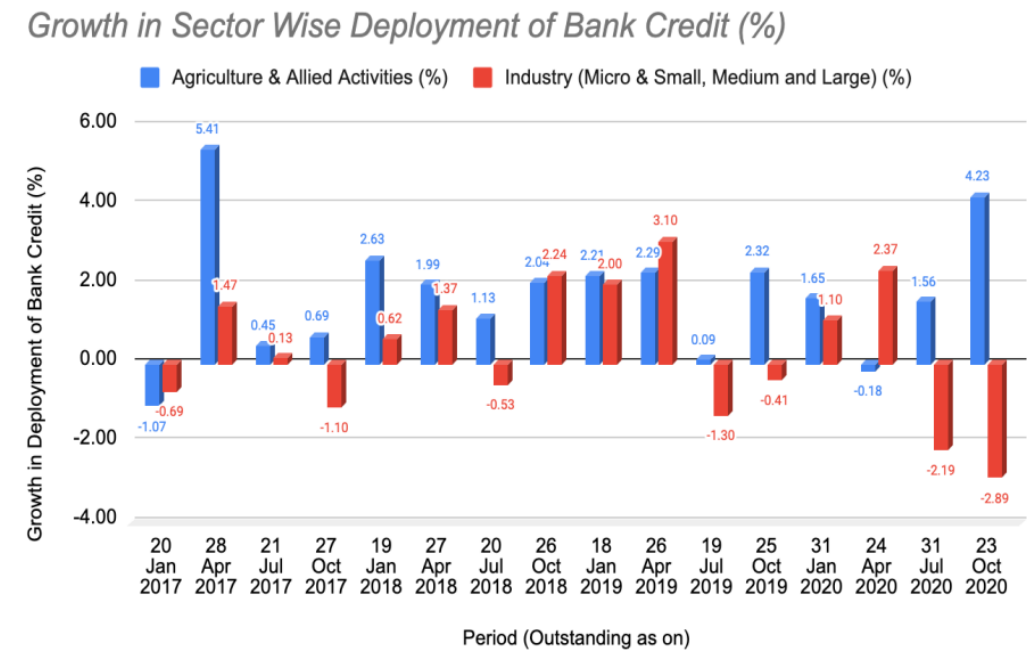

Growth in Sector Wise Deployment of Bank Credit (\%)

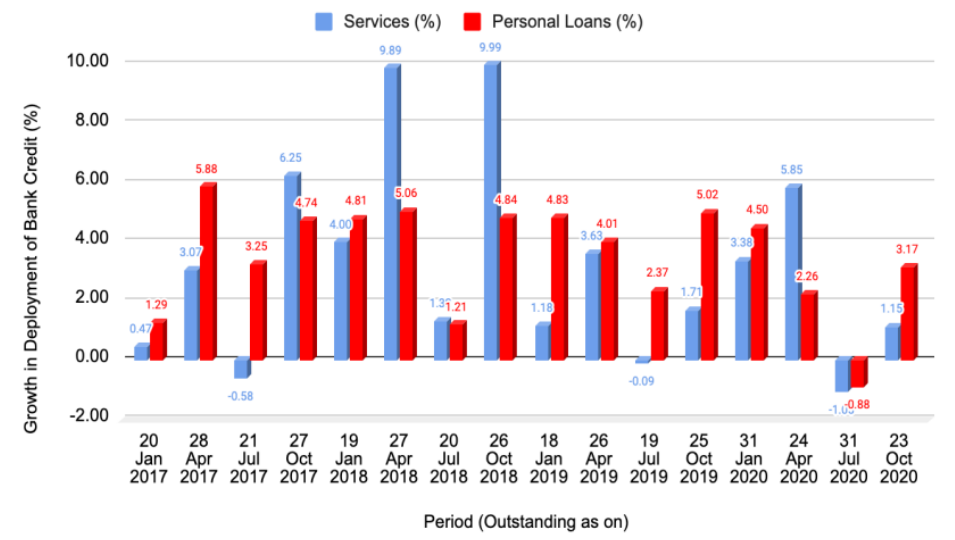

Source: Reserve Bank of India (2021)

When we have a look at the trends of growth or aggregate deposits and back credit, it is noticed that the back credit was in a decreasing trend since September 2019, reaching even 6.4 percent in March 2020, which is significantly lower than the value in April 2019 at 11.7 percent. Another reason for the decrease in the growth rate of credit growth rate was the Yes bank crisis which curtailed the growth rate by creating a risk for all private banks through a risk of deposit squeeze. 
International Journal of Social Science and Economic Research

ISSN: 2455-8834

Volume:06, Issue:06 "June 2021"

In fact the credit growth rate was around 14 percent in May 2019. Therefore the inception of COVID-19 had a negative impact on it.

Table 5.6.2: Annual Growth Rates for Aggregate Deposits and Bank Credit (\%)

\begin{tabular}{|c|c|c|c|}
\hline \multicolumn{4}{|c|}{ Annual Growth Rates for Aggregate Deposits and Bank Credit (\%) } \\
\hline Period & Aggregate Deposits & Bank Credit & $\begin{array}{c}\text { Credit Deposit } \\
\text { Ratio }(\%)\end{array}$ \\
\hline Jun:2017 & 12.6 & 8 & 72.8 \\
\hline Sep:2017 & 8.2 & 6.5 & 73.3 \\
\hline Dec:2017 & 4.1 & 10.7 & 75.1 \\
\hline Mar:2018 & 6.8 & 9.5 & 75.6 \\
\hline Jun:2018 & 7 & 11.1 & 75.6 \\
\hline Sep:2018 & 8.4 & 13.1 & 76.4 \\
\hline Dec:2018 & 9.3 & 12.9 & 77.6 \\
\hline Mar:2019 & 9.4 & 13.1 & 78.2 \\
\hline Jun:2019 & 10.1 & 11.7 & 76.7 \\
\hline Sep:2019 & 10.1 & 8.9 & 75.6 \\
\hline Dec:2019 & 10 & 7.4 & 75.7 \\
\hline Mar:2020 & 9.5 & 6.4 & 76 \\
\hline Jun:2020 & 11.5 & 6.4 & 73.1 \\
\hline Sep:2020 & 11 & 5.8 & 72 \\
\hline Dec:2020 & 11.1 & 6.2 & 72.5 \\
\hline
\end{tabular}

Source: Reserve Bank of India (2021)

The credit deposit ratio which indicates the capital adequacy ability of the bank has been at par with the ideal Credit deposit ratio which should be in the range 65-75 percent. Only in the 
International Journal of Social Science and Economic Research

ISSN: 2455-8834

Volume:06, Issue:06 "June 2021"

month of March 2019 and Mar 2020, the ratio lied above the ideal, indicator of an overstretched balance sheet. ${ }^{36}$

Figure 5.6.3 \& 5.6.4: Bank Credit Scenario(\%)
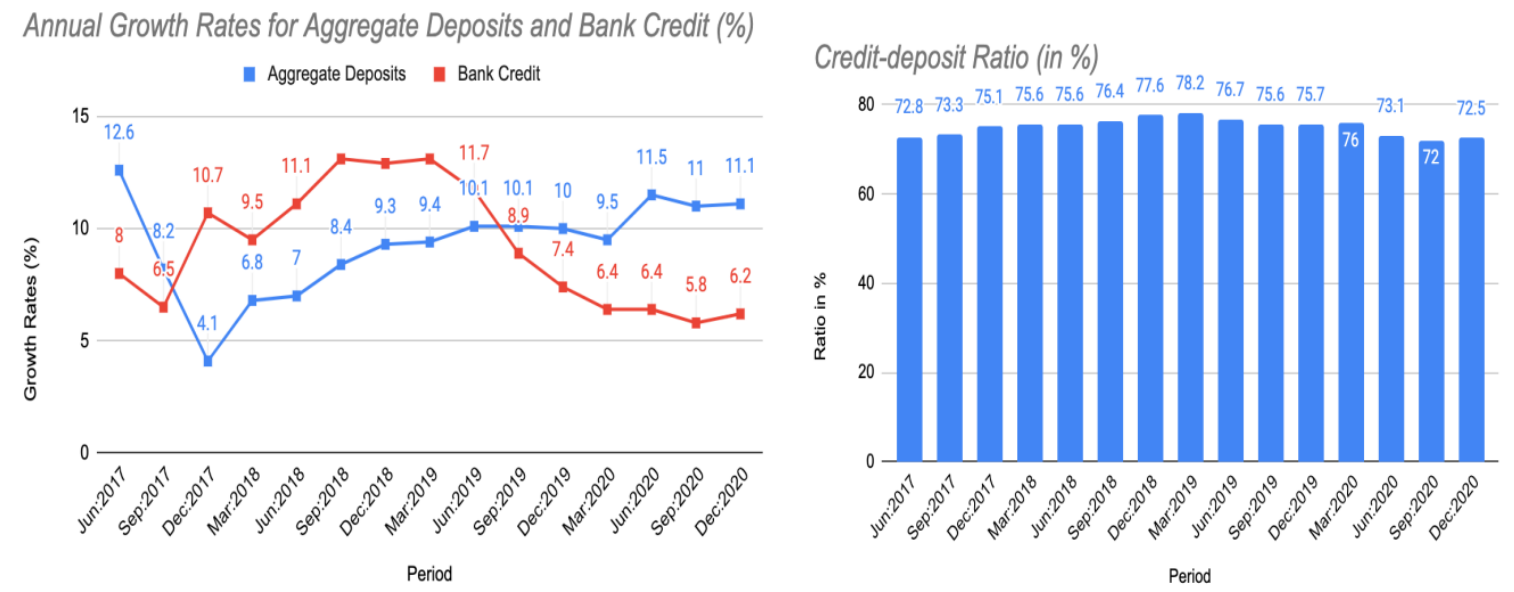

Source: Data Derived from the Reserve Bank of India (2021)

Bad loans have been a major problem for the Indian banking sector. A major factor that is responsible for increased NPAs is the external sector, where due to decrease in global commodity prices exports have slowed down significantly ${ }^{37}$.

Table 5.6.3: Annual Growth Rates for Aggregate Deposits and Bank Credit (\%)

\begin{tabular}{|c|c|}
\hline $\begin{array}{c}\text { GROSS NPA RATIO OF SCHEDULED } \\
\text { COMMERCIAL BANKS }\end{array}$ \\
\hline YEAR & $\begin{array}{c}\text { Gross NPAs to Gross } \\
\text { Advances Ratio (\%) }\end{array}$ \\
\hline 2016 & 7.48 \\
\hline 2017 & 9.32 \\
\hline
\end{tabular}

\footnotetext{
36 Reserve Bank wants banks to reduce CD ratio

37 Examining the rise of Non-Performing Assets in India
} 
International Journal of Social Science and Economic Research

ISSN: 2455-8834

Volume:06, Issue:06 "June 2021"

\begin{tabular}{|c|c|}
\hline 2018 & 11.18 \\
\hline 2019 & 9.08 \\
\hline 2020 & 8.21 \\
\hline 2021 (estimate) & 12.5 \\
\hline
\end{tabular}

Source: S \& P global ratings

Figure 5.6.5: Gross NPAs to Gross Advances ratio

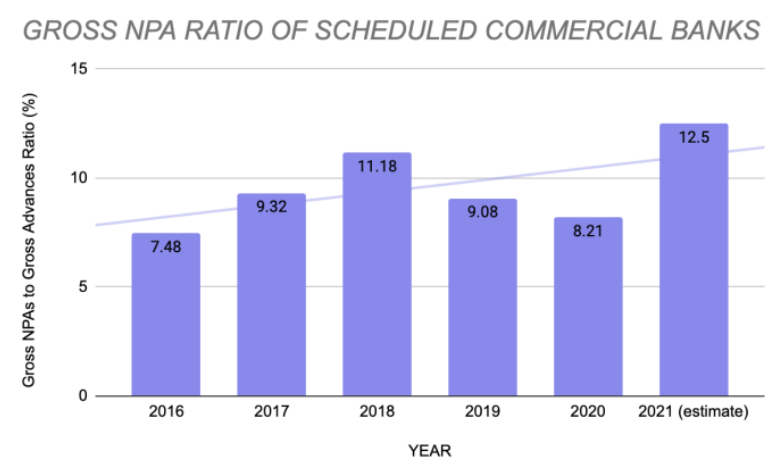

Source: S \& P global ratings

Even though the year 2019 received a slight relief from the previous year, at 9.08\%. The gross NPAs to gross advances ratio is estimated to increase to $12.5 \%$ in the year 2021. Thus following an upward trend from now on, highest in twenty years.

Table 5.6.4: Sector-wise new loans issued by SCBs

\begin{tabular}{|c|c|c|c|c|}
\hline \multicolumn{5}{|c|}{ Sector-wise New Loans by SCBs (y-0-y, per cent) } \\
\hline Sector & $\begin{array}{c}\text { Share in March 2020 } \\
(\%)\end{array}$ & $\begin{array}{c}\text { Q4:2019-20 } \\
\text { Growth }\end{array}$ & $\begin{array}{c}\text { Q1:2020-21 } \\
\text { Growth }\end{array}$ & $\begin{array}{c}\text { Q2:2020-21 } \\
\text { Growth }\end{array}$ \\
\hline Agriculture & 9.1 & -2 & -22.3 & 18 \\
\hline Industry & 35.4 & 19.3 & -20.2 & -15.4 \\
\hline
\end{tabular}


International Journal of Social Science and Economic Research

ISSN: 2455-8834

Volume:06, Issue:06 "June 2021"

\begin{tabular}{|c|c|c|c|c|}
\hline Services & 38.2 & 14.3 & -12.3 & -9.8 \\
\hline Personal Loans & 14.1 & 11.3 & -59.1 & 4.2 \\
\hline Others & 3.2 & -32 & -41.8 & -22.1 \\
\hline
\end{tabular}

Source: Reserve Bank of India (2021)

Figure 5.6.6 \& 5.6.7: Sector-wise new loans issued by SCBs
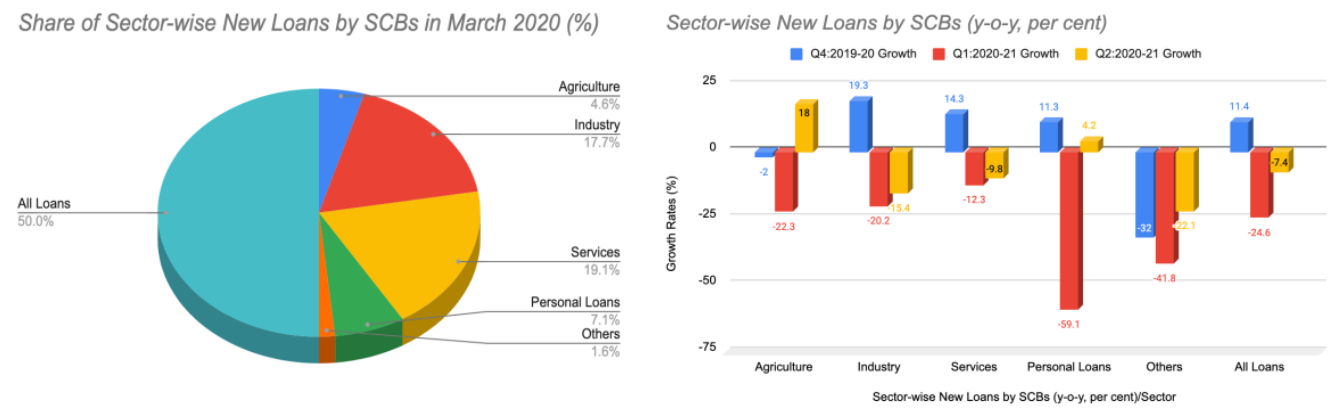

Source: Graphs derived from Reserve Bank of India (2021)

Industry and Services received the highest percentage of new loans from SCBs $35.4 \%$ and $38.2 \%$ respectively in the year ending March 2020. In the Q4 of 2019-20 the growth rate was overall already sluggish for agriculture. The Q1 2020-21, was the inception of COVID-19 along with which came a huge decrease in the growth rates of new loans for all sectors, agriculture at $22.3 \%$, personal loans at $-59.1 \%$ and industry at $-20.2 \%$. These rates improved slightly in the Q2, but still far away from reaching pre-COVID-19 figures. Even though lack of demand is one of the reasons for the decline of loans, however the banking sector is still quite reluctant to extend loans. ${ }^{38}$ The Banking sector in spite of government initiative to ping it back, has a long way to go before it reaches the levels before the pandemic.

\subsection{The Manufacturing Sector}

The manufacturing industry contributes 20 percent to India's GDP and around 60 percent of Indian exports are from the manufacturing industry (Jayaraman, 2020). The manufacturing sector was already slow before the beginning of the COVID-19 pandemic, due to an evident slowdown in the economy and sluggish demand prospects. Looking at the Purchasing Managers

38 RBI says banks reluctant to lend to big business. 
Index (PMI), a value above 50 indicates that the manufacturing sector is expanding, thus positive development, on the other hand a value below 50 indicates that there is contraction in the economy. ${ }^{39}$

\section{Figure 5.7.1: Purchasing Manufacturing Index (PMI)}

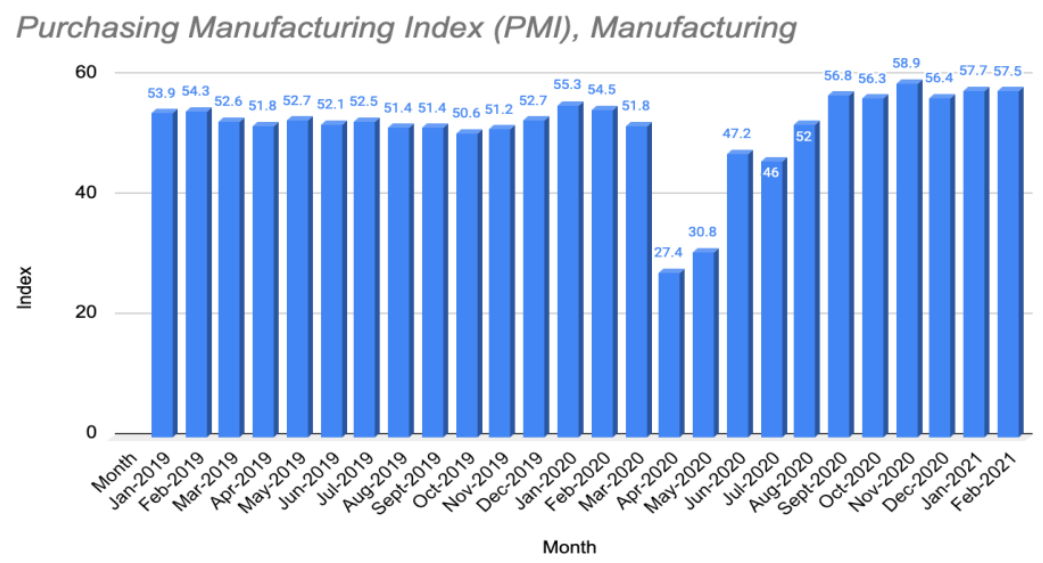

Source: The Global Economy (2021)

As exhibited in the graph above, the PMI index for manufacturing, fell dramatically in April 2020, reaching an all- time low of 27.4. This month was the first month of the great Indian lockdown, thus the contraction in business activity is inevitable, due to a stop on work in factories and production. The index remained low in the following months as well. However, soon enough the manufacturing sector was back on track, with the PMI being 57.5 in February 2021, indicating that it has bounced back and is on its path to recovery.

Table 5.7.1: Capacity Utilization in Manufacturing Sector

\begin{tabular}{|c|c|}
\hline \multicolumn{2}{|l|}{ CAPACITY UTILISATION IN } \\
MANUFACTURING SECTOR \\
\hline Period & CU (in \%) \\
\hline Q1: 2018-19 & 73.8 \\
\hline
\end{tabular}

${ }^{39}$ Economics for Everyone: Purchasing Managers' Index (PMI). 
International Journal of Social Science and Economic Research

ISSN: 2455-8834

Volume:06, Issue:06 "June 2021"

\begin{tabular}{|l|l|}
\hline Q2: 2018-19 & 74.8 \\
\hline Q3:2018-19 & 75.9 \\
\hline Q4: 2018-19 & 76.1 \\
\hline Q1:2019-20 & 73.6 \\
\hline Q2:2019-20 & 69.1 \\
\hline Q3:2019-20 & 68.6 \\
\hline Q4:2019-20 & 69.9 \\
\hline Q1: 2020-21 & 47.3 \\
\hline Q2: 2020-21 & 63.3 \\
\hline
\end{tabular}

Source: Reserve Bank of India Survey (2021)

The capacity utilization addresses the current operational efficiency of the manufacturing industry. During the first quarter of 2020-21, the capacity utilization decreased drastically from almost $70 \%$ to $47.3 \%$, indicating that the manufacturing industry was not using their machine and the machines were sitting idle. However in the second quarter of 2020-21, the capacity utilization was on a path of recovery and reached $63.3 \%$, indicating that in the near future that the operational capacity will be utilized due to recovery in the demand.

Figure 5.7.2: Index of Industrial Production (IIP)

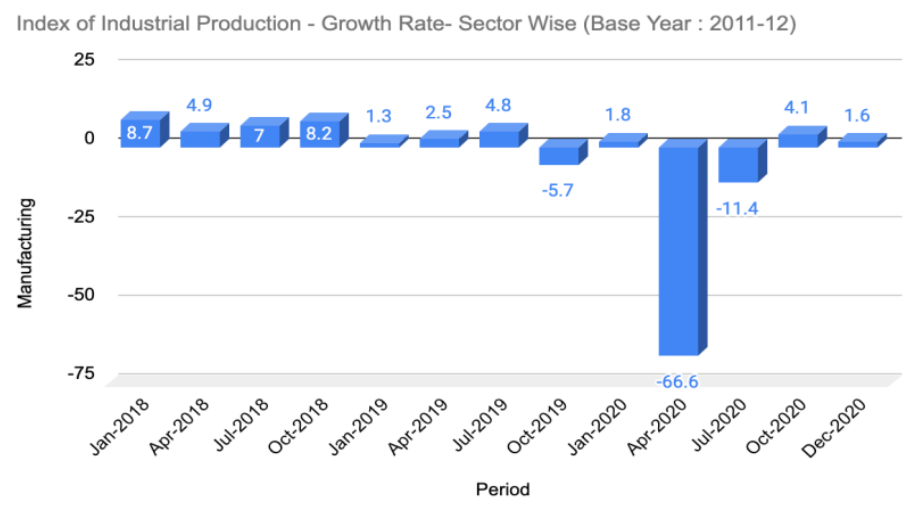

Source: Office of the Economic Advisor 
IIP shows the growth rates of the manufacturing industry, thus making it a very important economic indicator, indicating change in volume of production for the manufacturing sector. In April 2020 the IIP stood at $-66.6 \%$, which was due to the imposition of lockdown where manufacturing and production activities were not permitted. Even in July 2020, the growth rate remained negative at $-11.4 \%$ indicating that the industries were still not producing to their capacity. However, in October 2020 it raised to 4.1\%, indicating that after the unlock phase and the uplifting of restrictions, the manufacturing volume of production was increasing.

Table 5.7.2: Performance of Manufacturing sector- increase in production (Jan 2021)

\begin{tabular}{|c|c|c|c|}
\hline \multicolumn{5}{|c|}{ Performance of Manufacturing sector-Increase in production in January'2021 } \\
\hline Sr No & Item & Weights & $\begin{array}{c}\text { Growth Rates } \\
(\%)\end{array}$ \\
\hline & $\begin{array}{c}\text { Manufacture of wood and products of wood and cork, } \\
\text { except furniture; manufacture of articles of straw and } \\
\text { plaiting materials }\end{array}$ & 0.19 & 6.9 \\
\hline 2 & Manufacture of rubber and plastics products & 2.42 & 6.3 \\
\hline 3 & Manufacture of other transport equipment & 1.78 & 4.7 \\
\hline 4 & Manufacture of basic metals & 12.8 & 4.2 \\
\hline 5 & Manufacture of chemicals and chemical products & 7.87 & 3.1 \\
\hline
\end{tabular}

Source: Office of Economic Advisor

Table 5.7.3: Performance of Manufacturing sector- decrease in production (Jan 2021)

\begin{tabular}{|c|c|c|c|}
\hline \multicolumn{5}{|c|}{ Performance of Manufacturing Sector-Decrease in production in January'2021 } \\
\hline \multirow{2}{*}{ Sr No } & Item & Weights & $\begin{array}{c}\text { Growth Rates } \\
(\%)\end{array}$ \\
\hline 1 & Manufacture of wearing apparel & 1.32 & -20.2 \\
\hline 2 & Printing and reproduction of recorded media & 0.68 & -18.3 \\
\hline
\end{tabular}


International Journal of Social Science and Economic Research

ISSN: 2455-8834

Volume:06, Issue:06 "June 2021"

\begin{tabular}{|c|c|c|c|}
\hline 3 & Manufacture of furniture & 0.13 & -18 \\
\hline 4 & Manufacture of paper and paper products & 0.87 & -12.5 \\
\hline 5 & $\begin{array}{l}\text { Manufacture of pharmaceuticals, medicinal chemical and } \\
\text { botanical products }\end{array}$ & 4.98 & -11.5 \\
\hline 6 & Manufacture of tobacco products & 0.8 & -10.8 \\
\hline 7 & Manufacture of beverages & 1.04 & -8.5 \\
\hline 8 & Manufacture of machinery and equipment n.e.c & 4.77 & -7.6 \\
\hline 9 & Manufacture of other non-metallic mineral products & 4.09 & -6.1 \\
\hline 10 & Manufacture of textiles & 3.29 & -5.6 \\
\hline 11 & Manufacture of leather and related products & 0.5 & -4.9 \\
\hline 12 & Other manufacturing & 0.94 & -3.4 \\
\hline 13 & Manufacture of electrical equipment & 3 & -2.8 \\
\hline 14 & Manufacture of food products & 5.3 & -2.6 \\
\hline 15 & $\begin{array}{c}\text { Manufacture of fabricated metal products, except } \\
\text { machinery and equipment }\end{array}$ & 2.65 & -1.7 \\
\hline 16 & Manufacture of computer, electronic and optical products & 1.57 & -1 \\
\hline 17 & Manufacture of motor vehicles, trailers and semi-trailers & 4.86 & -0.9 \\
\hline 18 & Manufacture of coke and refined petroleum products & 11.77 & -0.5 \\
\hline
\end{tabular}

Source: Office of Economic Advisor

According to the Office of Economic advisor, manufacturing sub-sectors that increased their production are wood, rubber, plastic, transportation equipment, basic metals and chemical and chemical products. On the other hand, sub sectors like apparel, furniture, pen and paper products, beverages, machinery and equipment, textiles, electric equipment and food products experienced a decrease in their volume of production. There 18 sub-sectors of manufacturing that experienced a decreasing growth rate, indicating that the manufacturing industry still has a long way to go for expanding the manufacturing sector. 


\section{International Journal of Social Science and Economic Research}

ISSN: 2455-8834

Volume:06, Issue:06 "June 2021"

\subsection{Primary Research}

Numerous research surveys conducted have shown that the outbreak of Novel Coronavirus has evidently disrupted earning for Micro Small and Medium Enterprises in India by 20-50\%.Indian enterprises faced maximum heat primarily due to liquidity crunch. Whilst the majority of business involved in the MSME sector suffered losses, essentially commodity businesses picked up due to uninterrupted cash flows and foreseeable demand. Indian businesses tried to survive the pandemic by shifting their focus from non-essential to essential commodities such as production face masks and shields, sanitizer, grocery, toiletries, etc. The excess disruption of supply chains due to strict lockdown restrictions. Albeit COVID-19 paved a tough road for everyone businesses in rural India significantly got affected due to miniscule exposure to digital transformation. In order to understand the reaction of the local economy in lieu of Digital transformation we conducted a survey of 156 individuals running local businesses in Indian Markets. These local business owners were interviewed through digital questionnaires who classify their operations under MSME structure.

Figure 5.8.1 \& 5.8.2: Impact of the pandemic on the business
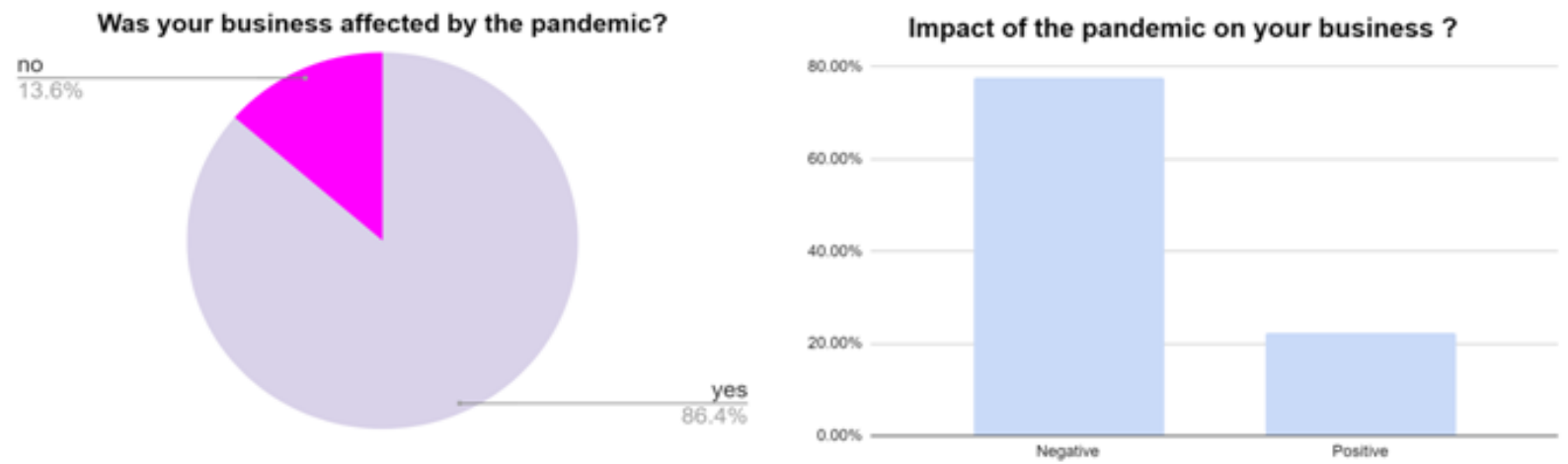

The initial results from the survey indicated that $86.4 \%$ of local business owners agreed that the pandemic did affect their operations in some manner whereas $13.6 \%$ claimed that it had no effect on their businesses. Out of 156 interviewees, nearly $77.8 \%$ of respondents asserted that pandemic has negatively impacted their business in comparison to $22.2 \%$ of them being positively impacted. 
International Journal of Social Science and Economic Research

ISSN: 2455-8834

Volume:06, Issue:06 "June 2021"

Figure 5.8.3: Scale of Operation

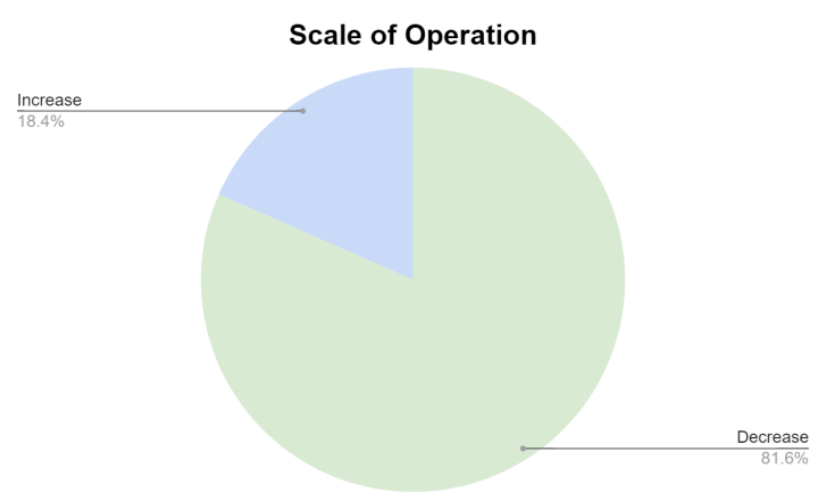

Assessing the business performance amidst the outbreak $81.6 \%$ of participants denoted a decrease in their scale of operations, this decline in scale can be attributed to heavy disruption of business cycles and supply chain constraints instilled due to unprecedented lockdown restrictions. Whilst majority of them indicated a decrease , $18.4 \%$ of them also reported an increase in operations, this increase could be due to increased demand for essential commodities during the peak lockdown months i.e. March and April 2020.

Figure 5.8.4: Business Profitability and Revenue

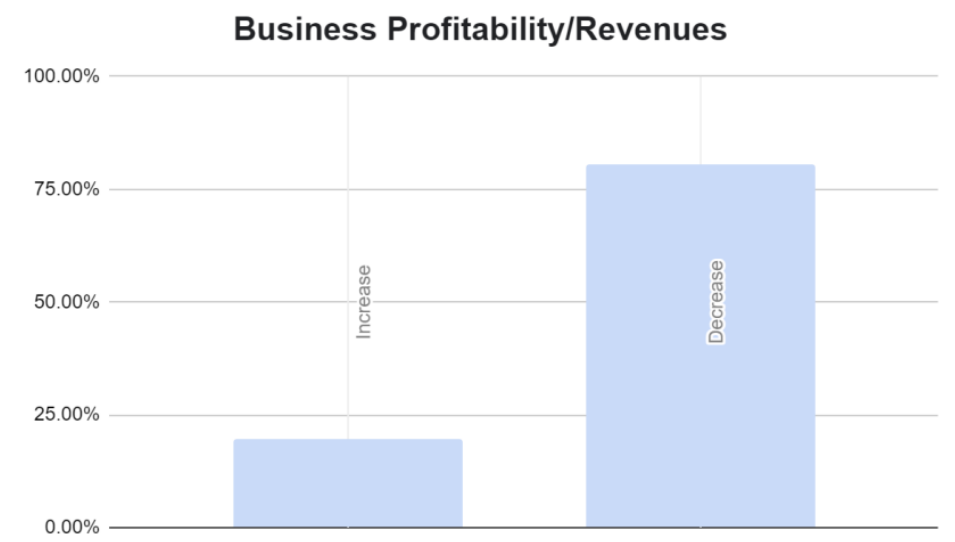

Since, essential commodities and tech were one of the few industries to experience a business uptick it should also be noted that the profitability margins are also lower in the grocery and essential commodities domain, for business shifting from non-essential to essential goods there are always significant setup cost and high operating expenses thereby dragging the profitability 
on a lower end. $80.6 \%$ of participants reported a decline in their profitability/ revenues during the pandemic, which is also reflective in their scale of operations response.

Table 5.8.1: Cross tabulation of Digital Transformation and Business Impact

\begin{tabular}{|c|c|c|c|}
\hline \multirow{4}{*}{ Business Impact } & & \multicolumn{2}{|c|}{ Digital Transformation } \\
\cline { 2 - 4 } & & Yes (\%) & no (\%) \\
\cline { 2 - 4 } & Positive (\%) & 22.60869565 & 21.95121951 \\
\cline { 2 - 4 } & Negative (\%) & 77.39130435 & 78.04878049 \\
\hline Total & & 115 & 41 \\
\hline
\end{tabular}

As per the Bank of Indonesia ${ }^{40}$, application of digital measures can significantly boost resilience amongst MSMEs to dodge the crisis. This survey also explores the digital transformation aspect of Indian Businesses.

Survey exhibited that $74.2 \%$ of owners agreed with the fact that amidst COVID-19 their business witnessed a digital transition. These transitions can be assessed in the form of operational tech, mode of payments, marketing etc. Introduction of digital transformation into the business ecosystem of India has prominently evolved Indian Business structures.

Figure 5.8.5: Digital Transformation vs Business impact

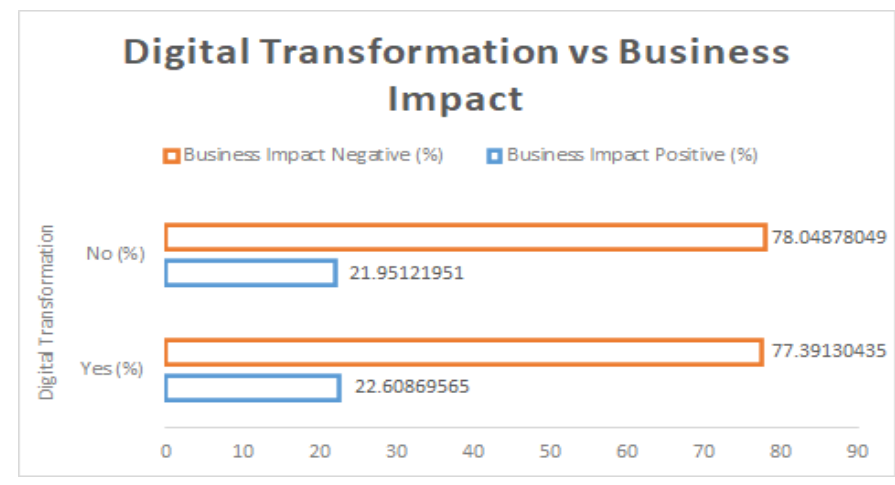

Metrics from our study indicated that $77 \%$ of business which witnessed digital transformation during the pandemic had a negative impact on their business which can be attributed to India's

${ }^{40}$ Pushing India's Boundaries with Digital Transformation 
inability to not create an environment conducive enough to generate positive results ${ }^{41}$. In China, over 50\% of top 18-20 companies are Digital whereas no India does not have any digital firms amongst its top players.

Samip Mutha , Group Head and Vice President of Digital Innovation, RPG group emphasized the importance of Digitalization in India to experience Industrial Transformation. Efficient implementation can help embrace this change by driving market differentiation and skill upgradation through scaling.

\section{Figure 5.8.6: Digital Transformation vs Scale of Operation}

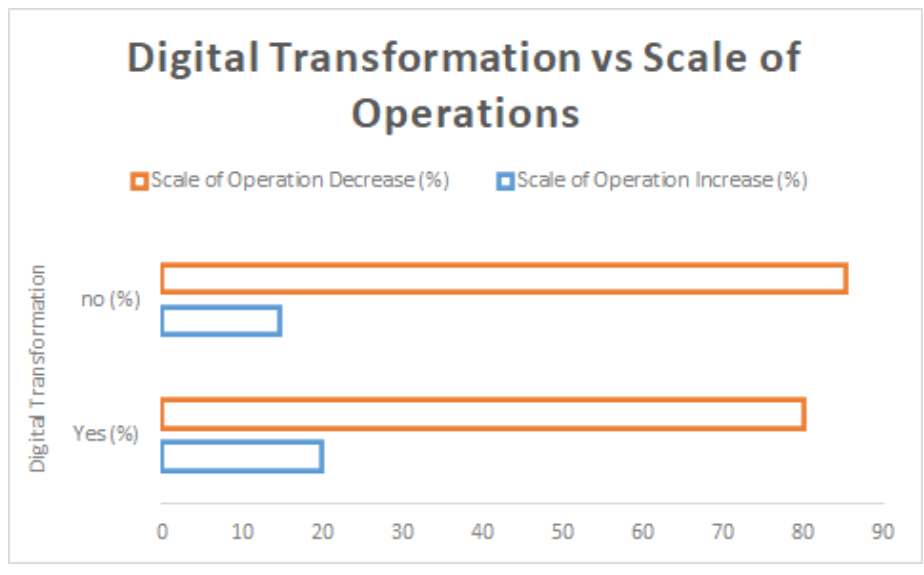

Table 5.8.1: Cross tabulation of Digital Transformation and Scale of Operation

\begin{tabular}{|c|c|c|c|}
\hline \multirow{3}{*}{ Scale of Operation } & \multicolumn{3}{|c|}{ Digital Transformation } \\
\cline { 2 - 4 } & & Yes (\%) & no (\%) \\
\cline { 2 - 4 } & Increase (\%) & 19.82758621 & 14.63414634 \\
\cline { 2 - 4 } & Decrease (\%) & 80.17241379 & 85.36585366 \\
\hline Total & & 116 & 41 \\
\hline
\end{tabular}

Despite concrete evidence of negative impact on business operations, this study shows that $80 \%$ of business suffered a decrease in scale of operations. While these figures indicate a slump in Indian MSME sector it also brings out strong implications for Indian government.

${ }^{41}$ It will be tough to make a lot of money in markets going ahead' 
Almost $75 \%$ of Indian population lacks the knowledge of basic finance and given it's thriving fintech ecosystem there lies a huge opportunity to educate Indian business owners ${ }^{42}$ This momentum gained digital financial inclusion can convert into a bankable opportunity through proper incentive programs.

Figure 5.8.7 Digital Transformation vs Business Performance

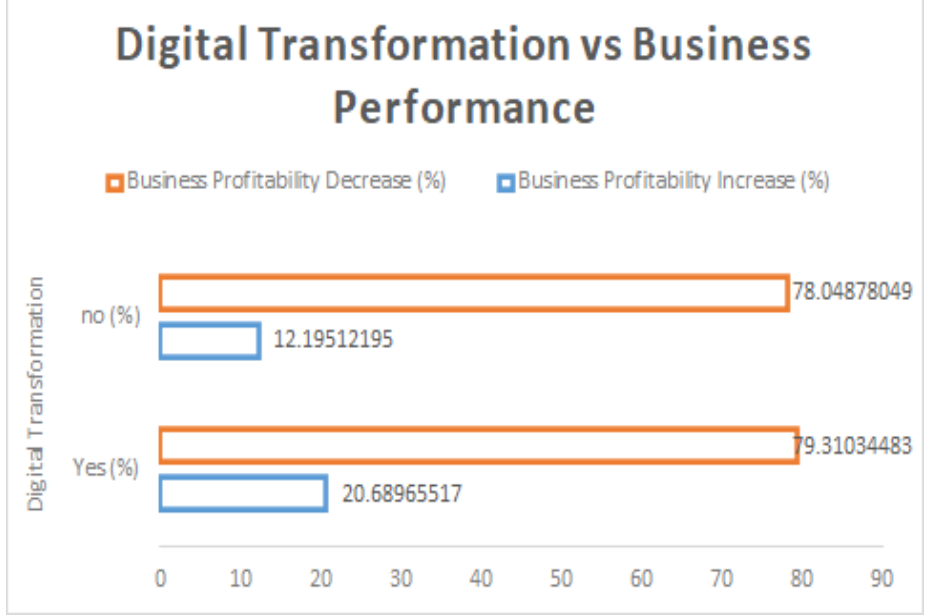

Through substantial investment in supply chains by the E-Commerce domain India has seen a rise in start-ups being able to gain national attention. A proper telecom and digital network will enable marginal sellers from remote and rural areas to access larger markets. Indian planning commissions can draw usable insights by shifting $79.3 \%$ of business which suffered decrease into the profitable section. Proper handholding support to MSMEs for understanding ecommerce functions can substantially leverage their expertise.

\section{Policy Implications and Recommendations}

Post 2008 crisis due to India's delayed action sowed seeds of long term economic backwardness , outbreak COVID-19 has reset India's economic environment for a V-shaped recovery. Although many scholars assert that the sizable income losses due to the pandemic will have to be deferred over numerous financial years to mitigate the effect, we feel that the crisis has created a little room for Indian Policy makers to revive the aforementioned sectors. Proceeding to the next part the paper discusses policy implications drawn in lieu of the analysis for each sector.

\section{Agriculture -}

42 'Technology is only as successful as the person harnessing it' -30 quotes of the week on digital transformation 
International Journal of Social Science and Economic Research

ISSN: 2455-8834

Volume:06, Issue:06 "June 2021"

a) Inclusion of farmers in Social Security programmes to ensure the protection of farm families and workers in the agricultural economy. Albeit farmers and workers are presumably involved in the production process despite they're prone to facing food shortage and unavailability problems. Hence programmes promoting in-kind assistance are necessary for farmer families, workers and tenant farmers as well.

b) Removal of export bans, in order to ensure that farmers and the sector can reap the benefits of greater market demand policy makers must ensure that export restrictions should not be considered as an alternative to tackle the access to food problem. Therefore , continuation of export for farm and agricultural products post COVID-19 is vital for the revival of the sector.

\section{Informal Sector}

a) Financial aid in the form of Cash transfers, although under numerous schemes the government has provided women with Rs.500 per month, experts argue that this amount might not be enough for survival. Hence, one time cash transfer programmes using NEFT system rather than Aadhar Payment Bridge system for women and vulnerable groups that are a part of India's undeclared economy are vital.

b) Access of national ration cards for migrant workers, these groups significantly suffered due to heavy lockdown restrictions, resource constraint and job security. It is essential the government must establish a traceable system to identify migrant workers and ensure their inclusion in one nation one ration card programme.

\section{Banking Sector}

a) Steps to address the mismatch between heightened risk aversion in the banking system and government liquidity influx schemes. Through issuance of proper government guidelines such as max. permissible loan amount per MSME/individual, eligibility criteria etc banks can identify the best firms and ensure efficient disbursement of loans

b) Recapitalisation of banks, instead of postponement and delay RBI should revitalise and revive the sector through tackling the NPAs and other defaulting borrowers. This will help the banks to rise from the consequences of loan moratorium and rising NPAs through adequate response and promising capital.

\section{Trade sector}


International Journal of Social Science and Economic Research

ISSN: 2455-8834

Volume:06, Issue:06 "June 2021"

a) Assistance for Indian Exporters (small players), majority of exporters are often unaware of WTO norms , global laws and requirements for International Trade. Hence organising workshops and information sessions and proper networking for reliable education on latest policies, trends , credit availability, IPR, patents is crucial for Indian Exporters

b) Schemes to bolster Indian exporters' position in global market, even though WTO ensures that national governments do not heavily subsidize local exporters it is vital for Indian government to take significant steps to push local business to the fundamental level in cut throat markets.

\section{MSME sector}

a) Setup of MSME survival fund, this package will comprise financial assistance necessary for revival of micro and small enterprises with extension of NPA norms to 135 days from 90 days. In addition, policies to promote extension of credit from $20 \%$ to $30 \%$ will help eradicate the grass root problem of liquidity crunch.

b) Deferment of EMIs , term liabilities and instalments as per the size of company thereby promoting faster payments in descending size method without affecting credit ratings can ensure survival of micro enterprises.

\section{Manufacturing Sector}

a) Direct tax incentive programme, manufacturing sector pickup slump can be revived through deferring TDS payments and statutory payments. Re-evaluation of "old vs new" tax policy and compensating enterprises for its potential impact.

b) Removal of geographical restrictions for inter-state migration of functions and setting up of new industries. Assistance with seamless warehousing and infrastructural options can build a safe harbour for the manufacturing sector given the profound impact of COVID19.

\section{Service Sector}

a) Price optimization of Turbine Fuel for Aviation industry and Tax rebate package, in lieu of slump caused due to suspension of International Travel and Domestic lockdowns government must ensure survival of companies and job security for employees in the industry. Furthering schemes such as UDAN can be another helpful initiative. 
International Journal of Social Science and Economic Research

ISSN: 2455-8834

Volume:06, Issue:06 "June 2021"

b) Due to significant losses in International Tourism demand amidst rising COVID-19 cases in India , policies to promote domestic tourism through tourism incentivization schemes with governments portals such as IRCTC, State transport authorities, Air India etc.

\section{Conclusion}

In conclusion, India's unprecedented rendezvous with COVID-19 transpired into a havoc for some of its finest industries thereby posing a prolonged challenge for policy makers. Indian Economy's dependence on these sectors have had a disruptive impact on employment, growth prospects and sustainability. It has caused not only a humanitarian crisis but has also caused a major economic downturn which the economy will take years to overcome.

Of the seven sectors examined in this study, the agricultural sector had little to no negative impact due to the COVID-19 pandemic. In the case of the service sector, the tourism and aviation sub-sector has suffered a major blow. The manufacturing sector was deeply affected by the COVID-19 pandemic with the factory production coming to a complete halt and capacity utilization levels extremely low. However, the economy's manufacturing sector has already started its run on its path to recovery. One interesting observation in the trade sector was a huge decline in the imports and exports of goods and services, which severely affected the trade volume and balance of the country. The banking sector is far off from the path of recovery, where the NPAs have reached an all-time high of two decades. Banks' reluctance to provide loans to small businesses has forced many MSMSs to completely shut down their operations. The informal economy has been on its worst since 2016, and COVID-19 has pushed these workers further back, depriving them their essential livelihood, with millions losing their jobs.

In lieu of India's huge informal economy unlike other advanced nations it is essential that immediate government intervention with effective policy response must be implemented. Assisting the unemployed with financial aids and ensuring sustenance of the aforementioned sectors is vital to minimize and mitigate the crisis. In addition to industry specific response government must evaluate the potential impact of COVID-19 regulations such as lockdowns, social distancing and curfews.

\section{Limitations \& Future Directions For The Study}

One of the limitations of this study is that the impact of COVID-19 on different sectors of the Indian economy cannot be determined for the long-run. Since this paper only emphasizes the impact on top performing sectors of the economy but there's room for detailed future research on the informal sectors which employ a significant half of the Indian Economy. 
International Journal of Social Science and Economic Research

ISSN: 2455-8834

Volume:06, Issue:06 "June 2021"

One interesting and important topic for future research can be determining the inter-linkages between different sectors of the economy, which can be built upon this research study. This can be done through econometric modelling with suitable time-series data which could not be carried out due to lack of updated time series data on performance indicators after the outbreak. The aim would be to analyse and compute the interlinkages and spill-overs between the sectoral impact. One example of such interlinkages is the analysing the impact of trade on the service sector, both in the Pre COVID-19 and COVID-19 era.

\section{References}

1. Agriculture in India - statistics \&amp; facts. (2021, January 8). Retrieved April 4, 2021, from $\quad$ https://www.statista.com/topics/4868/agricultural-sector-inindia/\#: :text=The $\% 20$ agriculture $\% 20$ sector $\% 20$ is $\% 20$ one, $18 \% 20$ percent $\% 20$ to $\% 20$ Indi a's\%20GDP.

2. Agriculture in India: Information About Indian Agriculture \&amp; Its Importance. (2021, March 22). Retrieved April 4, 2021, from https://www.ibef.org/industry/agricultureindia.aspx

3. Anand, Ishan \& Azad, Rohit. (2019). India's Slowdown: What It Is and What Can Be Done. Economic and political weekly. LIV. 11-16. and recovery. Retrieved from https://www.manufacturingtodayindia.com/sectors/7361-the-covid-19-lockdown-and-theindian-manufacturing-industry-effects-and-recovery

4. By: SEWA, By:, Sewa, Verbruggen, Y., By, Verbruggen, Y., . . Devenish, A. (2020). SEWA: Impact of Coronavirus on the Informal Economy. Retrieved from https://www.wiego.org/resources/sewa-impact-coronavirus-informal-economy

5. CEIC. (2021). India Non Performing Loans Ratio, 1998 - 2021: CEIC Data. Retrieved from https://www.ceicdata.com/en/indicator/india/non-performing-loansratio\#: :text=India Non Performing Loans Ratio stood at 8.2 \% in Mar,Mar 1998 to Mar 2020 .

6. Chaudhary, M., Sodani, P. R., \& Das, S. (2020). Effect of COVID-19 on Economy in India: Some Reflections for Policy and Programme. Journal of Health Management, 22(2), 169-180. doi:10.1177/0972063420935541

7. Coronavirus. (n.d.). Retrieved April 10, 2020, from https://www.who.int/emergencies/diseases/novel-coronavirus-2019 
International Journal of Social Science and Economic Research

ISSN: 2455-8834

Volume:06, Issue:06 "June 2021"

8. Das, Dr. Kishore Kumar and Patnaik, Shalini (2020). The Impact of COVID-19 in Indian Economy - An Empirical Study. International Journal of Electrical Engineering and Technology, 11(3), 2020, pp. 194-202., Retrieved from: https://ssrn.com/abstract $=3636058$

9. Department Of Agricultural Research and Education. (2021). Department of Agriculture Cooperation \& Farmers Welfare: Mo A\&FW: GoI. Retrieved from https://agricoop.nic.in/en/divisionalwebsite/department-agricultural-research-andeducation

10. Dev, \& Sengupta. (2020). Covid 19: Impact on the Indian Economy. Retrieved from http://www.igidr.ac.in/pdf/publication/WP-2020-013.pdf

11. Ernst \& Young Associates LLP. (2020). COVID-19: Impact on the financial services sector.

12. ET. (2020, May 15). Exports plunge by record 60.28\%in April; trade deficit lowest in 4 years. Retrieved from https://economictimes.indiatimes.com/news/economy/foreigntrade/covid-19-impact-exports-plunge-60-28-pc-inapril/articleshow/75760239.cms?from $=\mathrm{mdr}$

13. Hindu. (2020, March 05). COVID-19: Trade impact for India estimated at $\$ 348$ million: UN report. Retrieved from https://www.thehindu.com/business/Economy/covid-19-tradeimpact-for-india-estimated-at-348-million-un-report/article30987932.ece\#

https://www.researchgate.net/publication/336412893 India's Slowdown What It Is an d What Can Be Done

IMF. (2020). Policy Responses to COVID19. Retrieved from https://www.imf.org/en/Topics/imf-and-covid19/Policy-Responses-to-COVID-19\#I

14. Jadhav, R. (2021, January 4). Covid-19 lockdowns: How much did the unorganised sector lose? The Hindu Business Line. Retrieved April 4, 2021, from https://www.thehindubusinessline.com/economy/covid-19-lockdowns-how-much-didthe-unorganised-sector-lose/article33491316.ece

15. Jayaraman. (2020). The COVID 19 Lockdown and the Indian manufacturing industry effects 
International Journal of Social Science and Economic Research

ISSN: 2455-8834

Volume:06, Issue:06 "June 2021"

16. Jena. (2020). IMPACT OF PANDEMIC COVID 19 ON EDUCATION IN INDIA. Retrieved

from

https://poseidon01.ssrn.com/delivery.php?ID=1001040640081191100741190900210831

260600490300430690350290001050101100161190040940970561020180160381200290

210650740061090840921050840130780670680710760970710880850870020590241110

990290030990030240860990850691071150850731210830710100260700660951000900

$17 \& \mathrm{EXT}=\mathrm{pdf}$.

17. Khan, F., \& Mansoor, K. (2020, May 11). COVID-19 impact: Informal economy workers excluded from most govt measures, be it cash transfers or tax benefits. Retrieved April 4, 2021, from https://www.firstpost.com/business/covid-19-impact-informal-economyworkers-excluded-from-most-govt-measures-be-it-cash-transfers-or-tax-benefits$\underline{8354051 . h t m l}$

18. Kohli, F. (2020, August 08). Covid crisis: Why India needs to worry about its services economy. Retrieved from https://www.financialexpress.com/opinion/covid-crisis-whyindia-needs-to-worry-about-its-services-economy/2048478/

19. Kumar, B.V.D.s. (2020). A STUDY ON COVID EFFECT ON INDIAN SERVICE SECTOR.

20. Maitra, A. K. (2020, May 30). What is it that ails our informal sector? The Indian Express. Retrieved April 4, 2021, from https://www.newindianexpress.com/opinions/2020/may/30/what-is-it-that-ails-ourinformal-sector-

2149869.html\#: :text=They\%20effectively\%20constitute $\% 2090 \% 25 \% 20$ of,50\%25\%20o f\%20the\%20total\%20GDP

21. Mckibbin, W. J., \& Fernando, R. (2020). The Global Macroeconomic Impacts of COVID-19: Seven Scenarios. SSRN Electronic Journal. doi: 10.2139/ssrn.3547729

22. Mehrotra, S. (2019). Informal Employment Trends in the Indian Economy: Persistent informality, but growing positive development. Employment Policy Department - ILO, 131. Retrieved April 4, 2021, from https://www.ilo.org/wcmsp5/groups/public/---ed emp/--ifp skills/documents/publication/wcms 734503.pdf

23. MOSPI. (2021). KPI Dashboard. $\quad$ Retrieved from http://mospi.nic.in/dashboard/dashboard/nad 


\section{International Journal of Social Science and Economic Research}

ISSN: $2455-8834$

Volume:06, Issue:06 "June 2021"

24. Nair. (2020, June 30). Covid-19 Impact: Bad Loans May Rise To A Near Two-Decade High, Says S\&P. Retrieved from https://www.bloombergquint.com/economyfinance/covid-19-impact-bad-loans-may-rise-to-a-near-two-decade-high-says-sp

25. Nandakumar, V. (2019, June 07). Financing MSMEs: The continuing challenge. Retrieved from https://www.fortuneindia.com/opinion/financing-msmes-the-continuingchallenge/103287

26. Nordea Trade Portal. (2021). Foreign trade figures of India. Retrieved from https://www.nordeatrade.com/en/explore-new-market/india/trade-profile

27. Principles of Epidemiology: Lesson 6, Section 2|Self-Study Course SS1978|CDC. (2016, September 15).

Retrieved

from https://www.cdc.gov/csels/dsepd/ss1978/lesson6/section2.html

28. PRS. (2018, September 13). Examining the rise of Non-Performing Assets in India. Retrieved from https://www.prsindia.org/content/examining-rise-non-performing-assetsindia

29. Rakshit, Debdas and Paul, Ananya (2020). Impact of COVID-19 on Sectors of Indian Economy and Business Survival Strategies. Retrieved from https://ssrn.com/abstract=3620727 or http://dx.doi.org/10.2139/ssrn.3620727

30. Rawal, Kumar, Verma, \& Pais. (2020). COVID-19 Lockdown: Impact on Agriculture and Rural Economy. Retrieved from https://www.networkideas.org/wpcontent/uploads/2020/06/sserwp2003.pdf.

31. Sahoo, Jyoti Prakash \& Samal, Kailash. (2020). Impact of COVID-19 on Indian Agriculture. Retrieved from https://www.researchgate.net/publication/341977760 Impact of COVID19 on Indian Agriculture

32. Sahoo, P., \& Ashwani. (2020). COVID-19 and Indian Economy: Impact on Growth, Manufacturing, Trade and MSME Sector. Global Business Review, 21(5), 1159-1183. doi:10.1177/0972150920945687

33. Shekar, \& Mansoor. (2020). COVID-19: Lockdown Impact on Informal Sector in India. Retrieved from https://practiceconnect.azimpremjiuniversity.edu.in/covid-19-lockdownimpact-on-informal-sector-in-india/. 
International Journal of Social Science and Economic Research

ISSN: 2455-8834

Volume:06, Issue:06 "June 2021"

34. Shekar, C., \& Mansoor, K. (2020). Lockdown Impact on Informal Sector in India. People's Archive of Rural India, 1-12.

35. Srinivasan, Karthik, \& Saggar. (2020). COVID-19 Impact on financial services entities. Retrieved from https://www.icraresearch.in/research/ViewResearchReport/2896.

36. UNCTAD. (2020). Global trade impact of the Coronavirus (Covid-19) epidemic. Retrieved from https://unctad.org/system/files/official-document/ditcinf2020d1.pdf.

37. Varshney, Roy, \& Meenakshi. (2020). Impact of COVID-19 on agricultural markets: Assessing the roles of commodity characteristics, disease caseload and market reforms.

38. WHO Coronavirus Disease (COVID-19) Dashboard. (n.d.). Retrieved from https://covid19. who.int/?gclid=CjwKCAiA-

f78BRBbEiwATKRRBA91QloJQXRRXfa06rUSpbakAceD0iIRQQ5TXfardc4aDRi6bNu W-BoCDvIQAvD BwE

\section{Appendix}

Table 10.1

\begin{tabular}{|c|c|c|}
\hline \multicolumn{3}{|c|}{ Purchasing Managers Index (PMI), Services } \\
\hline Sr No & Month & Index \\
\hline 1 & Jan-2019 & 52.2 \\
\hline 2 & Feb-2019 & 52.5 \\
\hline 3 & Mar-2019 & 52 \\
\hline 4 & Apr-2019 & 51 \\
\hline 5 & May-2019 & 50.2 \\
\hline 6 & Jun-2019 & 49.6 \\
\hline 7 & Jul-2019 & 53.8 \\
\hline 8 & Aug-2019 & 52.4 \\
\hline 9 & Sept-2019 & 48.7 \\
\hline 10 & Oct-2019 & 49.2 \\
\hline 11 & Nov-2019 & 52.7 \\
\hline 12 & Dec-2019 & 53.3 \\
\hline
\end{tabular}


International Journal of Social Science and Economic Research

ISSN: 2455-8834

Volume:06, Issue:06 "June 2021"

\begin{tabular}{|c|c|c|}
\hline 13 & Jan-2020 & 55.5 \\
\hline 14 & Feb-2020 & 57.5 \\
\hline 15 & Mar-2020 & 49.3 \\
\hline 16 & Apr-2020 & 5.4 \\
\hline 17 & May-2020 & 12.6 \\
\hline 18 & Jun-2020 & 33.7 \\
\hline 19 & Jul-2020 & 34.2 \\
\hline 20 & Aug-2020 & 41.8 \\
\hline 21 & Sept-2020 & 49.8 \\
\hline 22 & Oct-2020 & 54.1 \\
\hline 23 & Nov-2020 & 53.7 \\
\hline 24 & Dec-2020 & 52.3 \\
\hline 25 & Jan-2021 & 52.8 \\
\hline 26 & Feb-2021 & 55.3 \\
\hline
\end{tabular}

Table 10.2

\begin{tabular}{|c|c|}
\hline \multicolumn{2}{|c|}{ Foreign Tourists Arriving in India (million) } \\
\hline Year & In Million \\
\hline 2016 & 8.8 \\
\hline 2017 & 10.2 \\
\hline 2018 & 11 \\
\hline 2019 & 11 \\
\hline 2020 (upto June 2020) & 3 \\
\hline
\end{tabular}

Table 10.3

\begin{tabular}{|c|c|}
\hline \multicolumn{2}{|c|}{ Foreign Exchange Earnings from Tourism in India (US\$ billion) } \\
\hline Year & (US\$ billion) \\
\hline 2016 & 23.2 \\
\hline
\end{tabular}


International Journal of Social Science and Economic Research

ISSN: 2455-8834

Volume:06, Issue:06 "June 2021"

\begin{tabular}{|c|c|}
\hline 2017 & 27.7 \\
\hline 2018 & 28.6 \\
\hline 2019 & 30 \\
\hline 2020 (upto June 2020) & 6.2 \\
\hline
\end{tabular}

Table 10.4

\begin{tabular}{|c|c|c|}
\hline \multicolumn{3}{|c|}{ Purchasing Manufacturing Index (PMI), Manufacturing } \\
\hline Sr No & Month & Index \\
\hline 1 & Jan-2019 & 53.9 \\
\hline 2 & Feb-2019 & 54.3 \\
\hline 3 & Mar-2019 & 52.6 \\
\hline 4 & Apr-2019 & 51.8 \\
\hline 5 & May-2019 & 52.7 \\
\hline 6 & Jun-2019 & 52.1 \\
\hline 7 & Jul-2019 & 52.5 \\
\hline 8 & Aug-2019 & 51.4 \\
\hline 9 & Sept-2019 & 51.4 \\
\hline 10 & Oct-2019 & 50.6 \\
\hline 11 & Nov-2019 & 51.2 \\
\hline 12 & Dec-2019 & 52.7 \\
\hline 13 & Jan-2020 & 55.3 \\
\hline 14 & Feb-2020 & 54.5 \\
\hline 15 & Mar-2020 & 51.8 \\
\hline 16 & Apr-2020 & 27.4 \\
\hline 17 & May-2020 & 30.8 \\
\hline 18 & Jun-2020 & 47.2 \\
\hline 19 & Jul-2020 & 46 \\
\hline 20 & Aug-2020 & 52 \\
\hline 21 & Sept-2020 & 56.8 \\
\hline
\end{tabular}


International Journal of Social Science and Economic Research

ISSN: 2455-8834

Volume:06, Issue:06 "June 2021"

\begin{tabular}{|c|c|c|}
\hline 22 & Oct-2020 & 56.3 \\
\hline 23 & Nov-2020 & 58.9 \\
\hline 24 & Dec-2020 & 56.4 \\
\hline 25 & Jan-2021 & 57.7 \\
\hline 26 & Feb-2021 & 57.5 \\
\hline
\end{tabular}

Table 10.5

\begin{tabular}{|c|c|c|c|c|}
\hline \multicolumn{5}{|c|}{ Index of Industrial Production - Growth Rate- Sector Wise (Base Year : 2011-12) } \\
\hline Sr No & Period & Manufacturing & Electricity & General Index \\
\hline 1 & Jan-2018 & 8.7 & 7.6 & 7.5 \\
\hline 2 & Apr-2018 & 4.9 & 2.1 & 4.5 \\
\hline 3 & Jul-2018 & 7 & 6.6 & 6.5 \\
\hline 4 & Oct-2018 & 8.2 & 10.8 & 8.4 \\
\hline 5 & Jan-2019 & 1.3 & 0.9 & 1.6 \\
\hline 6 & Apr-2019 & 2.5 & 6 & 3.2 \\
\hline 7 & Jul-2019 & 4.8 & 5.2 & 4.9 \\
\hline 8 & Oct-2019 & -5.7 & -12.2 & -6.6 \\
\hline 9 & Jan-2020 & 1.8 & 3.1 & 2.2 \\
\hline 10 & Apr-2020 & -66.6 & -22.9 & -57.3 \\
\hline 11 & Jul-2020 & -11.4 & -2.5 & -10.5 \\
\hline 12 & Oct-2020 & 4.1 & 11.2 & 4.2 \\
\hline 13 & Dec-2020 & 1.6 & 5.1 & 1 \\
\hline
\end{tabular}

